\title{
Electron delocalization in vinyl ruthenium substituted cyclophanes: Assessment of the through-space and the through-bond pathways
}

\author{
Philipp Mücke ${ }^{\mathrm{a}}$, Manfred Zabel ${ }^{\mathrm{b}}$, Ruth Edge ${ }^{\mathrm{c}}$, David Collison ${ }^{\mathrm{c}}$, Sébastien Clément ${ }^{\mathrm{d}, 1}$, Stanislav Záliš ${ }^{\mathrm{e}, *}$ \\ Rainer F. Winter ${ }^{\mathrm{a}, * *}$

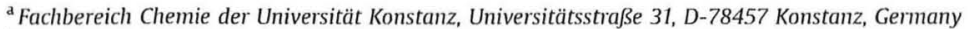 \\ ${ }^{\mathrm{b}}$ Institut für Anorganische Chemie, Fachbereich Chemie und Pharmazie der Universität Regensburg, Universitätsstraße 31, D-93040 Regensburg, Germany \\ ${ }^{c}$ EPSRC National EPR Service, University of Manchester, School of Chemistry, Oxford Road, Manchester, M13 9PL, United Kingdom \\ 'Institut UTINAM UMR CNRS 6213, Université de Franche Comté, 25030 Besançon, France \\ ${ }^{\mathrm{e}}$ J. Heyrovský Institute of Physical Chemistry, v.v.i, Academy of Sciences of the Czech Republic, Czech Republic
}

Keywords:

Vinyl complexes

Ruthenium

Cyclophanes

Electrochemistry

Spectroelectrochemistry

Mixed-valent

\begin{abstract}
A B S T R A C T
Pseudo-para[2.2]paracyclophane- and [2.1] orthocyclophane-bridged diruthenium complexes 2 and $\mathbf{3}$ with two interlinked electroactive styryl ruthenium moieties have been prepared and investigated. Both complexes undergo two reversible consecutive one-electron oxidation processes which are separated by 270 or $105 \mathrm{mV}$. Stepwise electrolysis of the neutral complexes to first the mixed-valent radical cations and then the dioxidized dications under IR monitoring reveal incremental shifts of the charge-sensitive $\mathrm{Ru}(\mathrm{CO})$ bands and allow for an assignment of their radical cations as moderately or very weakly coupled mixed-valent systems of class II according to Robin and Day. Ground-state delocalization in the mixedvalent forms of these complexes as based on the CO band shifts is considerably larger for the "closed" paracyclophane as for the "half-open" orthocyclophane. Experimental findings are backed by the calculated IR band patterns and spin density distributions for radical cations of slightly simplified model complexes $\mathbf{2}^{\mathrm{Me}++}$ and $\mathbf{3}^{\mathrm{Me}+}$ with the $\mathrm{P}^{i} \mathrm{Pr}_{3}$ ligands replaced by $\mathrm{PMe}_{3}$. Radical cations $\mathbf{2}^{++}$and $\mathbf{3}^{++}$feature a characteristic NIR band that is neither present in their neutral or fully oxidized forms nor in the radical cation of the monoruthenium [2.2]paracyclophane complex $\mathbf{1}$ with just one vinyl ruthenium moiety. These bands are thus assigned as intervalence charge-transfer (IVCT) transitions. Our results indicate that, for the radical cations, electronic coupling "through-space" via the stacked styrene decks is significantly more efficient than the "through-bond" pathway.
\end{abstract}

\section{Introduction}

$\pi$-Stacking has long been recognized as an important noncovalent interaction governing the organization of matter [1-5]. Implications are numerous and include, inter alia, the photophysics of luminophores [6-8] or of polymers having extended arene substituents or backbones $[9,10]$, the formation of self-assembled coordination cages $[3,5,11]$ and the exchange of magnetic [12-18] or electronic information [8,16,19-28]. $\pi$-Stacking is also held responsible for rapid charge migration over oligonucleotides and

\footnotetext{
* Corresponding author

** Corresponding author. Tel.: +49 7531 885355; fax: +49 75318883136 .

E-mail addresses: stanislav.zalis@jh-inst.cas.cz. (S. Záliš), rainer.winter@unikonstanz.de (R.F. Winter).

1 Present address: Institut Charles Gerhardt - UMR5253, Equipe CMOS (Chimie Moléculaire et Organisation du Solide), Université de Montpellier 2 - CC1701, Place Eugène Bataillon, F-34095 Montpellier Cedex 05, France.
}

DNA [29-32] or columnar mesophases made up of suitably functionalized disk-shaped building blocks with extended aromatic cores [32-37]. Hupp et al. have beautifully demonstrated that rectangular tetrametal box molecules with extended diimine $\pi$ ligands as the long sides form, upon partial reduction, mixed-valent radical anions that exhibit electronic coupling through-space [38-40]. A clear dependency of the strength of the electronic interaction on the stacking distance was observed.

[n.n]Paracyclophanes have a particularly successful history as testbeds for such interactions [41-44]. The groups of Neugebauer [45,46] and, more recently, Grampp and Lambert [47] have elegantly utilized the radical cations derived from electron-rich methoxy or bis(triarylamine) substituted [n.n]paracyclophanes as probes for electron delocalization on the EPR timescale and noted that cyclophane bridges behave more like unsaturated and conjugated than as saturated bridges in terms of the electronic coupling conveyed by them [42]. 
We herein report [2.2]paracyclophanes where one or both arene decks are elaborated into styryl ruthenium moieties $\mathrm{RuCl}(\mathrm{CH}=$ CHPh' $)(\mathrm{CO})\left(\mathrm{P}^{i} \mathrm{Pr}_{3}\right)_{2}$. The $\left\{\mathrm{RuCl}(\mathrm{CO})\left(\mathrm{P}^{i} \mathrm{Pr}_{3}\right)_{2}\right\}$ tags render the corresponding styryl substituents electroactive at fairly low potential and stabilize their associated radical cations to about the same extent as dialkyl amino groups, thus making them amenable to spectroscopic investigations. As an added benefit with respect to classical organic electron donating groups they also provide the characteristic $\mathrm{Ru}(\mathrm{CO})$ stretch as a reporter of the charge density at the metal center. Its change in position upon oxidation is a convenient spectroscopic probe of the loss of electron density from the metal atom. Moreover, the $\mathrm{CO}$ band pattern and the relative $\mathrm{CO}$ band shifts are indicative of the degree of intrinsic charge delocalization on the short vibrational timescale of $\mathrm{ca} .10^{-12} \mathrm{~s}$ in di- and oligonuclear complexes. Here we apply these $\mathrm{Ru}(\mathrm{CO})$ tags to measure electron delocalization in a diruthenium pseudo-para-divinyl[2.2] paracyclophane complex. The issue of the contribution of the saturated alkylene straps to the overall electron delocalization is addressed by comparison with the 3,7-divinyl-10,11-dihydro-5Hdibenzo[a,d]cycloheptene-derived diruthenium complex 3 that maintains the motif of two doubly alkyl linked styryl ruthenium moieties but lacks the $\pi$-stacking of the individual styryl ruthenium subunits as it is present in paracyclophanes (see Chart I).

\section{Experimental section}

\subsection{General considerations}

All reactions and manipulations were conducted using standard Schlenk techniques. Solvents were dried over appropriate drying agents, distilled under nitrogen and stored in airtight glass bulbs. All NMR solvents were degassed by five "freeze-pump-thaw" cycles and stored in airtight Schlenk tubes over appropriate molecular sieves. ${ }^{1} \mathrm{H},{ }^{13} \mathrm{C}$ and ${ }^{31} \mathrm{P}$ NMR spectra were recorded on a Bruker Avance $300(300.13 \mathrm{MHz})$ or a Bruker Avance 400 $(400.13 \mathrm{MHz})$ NMR spectrometer. Voltammetric measurements were conducted on an Epsilon ${ }^{\mathrm{TM}}$ potentiostat from BASi (Bioanalytical Systems, Inc.) using a cylindrical airtight onecompartment cell with a spiral silver wire as reference electrode,

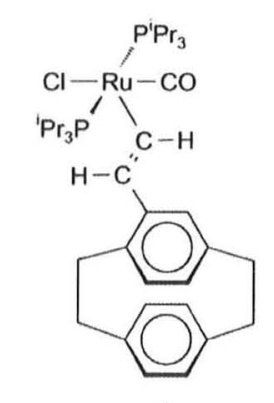

1

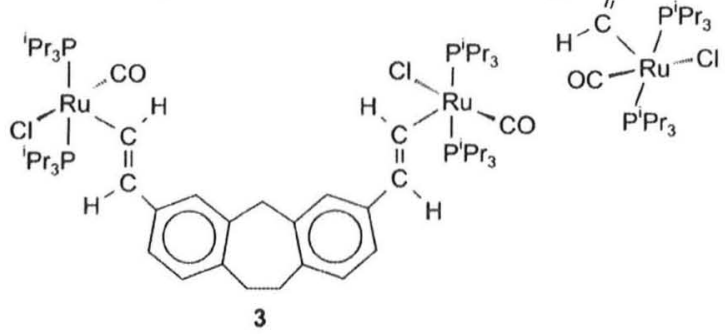

Chart 1. a platinum wire as counter electrode and a platinum working electrode (Pt $\emptyset=1.1 \mathrm{~mm}$, BASi). Measurements were performed under an argon atmosphere on $0.1 \mathrm{M}$ solutions of $\mathrm{NBu}_{4} \mathrm{PF}_{6}$ in dried $\mathrm{CH}_{2} \mathrm{Cl}_{2}$ and referenced to the $\mathrm{Cp}_{2} \mathrm{Fe}^{\mathrm{O} /+}$ couple with ferrocene or decamethylferrocene as an internal standard. The respective standard was added after all necessary data on the analyte had been acquired. Representative scans were then repeated in the presence of the standard. IR and spectroelectrochemical measurements were recorded on a Nicolet iS10 instrument of ThermoFischer. UV/Vis/ NIR experiments were performed on an OMEGA 20 spectrometer of Bruins Instruments or a TIDAS fiberorptic diode array spectrometer (combined MCS UV/NIR and PGS NIR instrumentation) from $\mathrm{j} \& \mathrm{~m}$ in a home-built OTTLE-cell following the basic design of F. Hartl et al. [48]. EPR spectra were recorded at the EPSRC Multi-Frequency c.w. EPR Service Centre at the University of Manchester on a Bruker EMX spectrometer with different microwave bridges (X-band $(\approx 9.4 \mathrm{GHz})$ and S-band $(\approx 3.8 \mathrm{GHz}))$. The temperature of the sample was controlled by evaporation of liquid nitrogen and a heater, using a digital temperature and gas flow control unit and quartz cavity insert (X-band) or quartz immersion Dewar (S-band), and was monitored with a thermocouple close to the sample position. For EPR spectroscopic experiments, quartz tubes of $1 \mathrm{~mm}$ inner diameter for X-band and of $3 \mathrm{~mm}$ inner diameter for S-band measurements were used. In situ EPR spectroelectrochemical experiments were carried out in dichloromethane with $0.1 \mathrm{M}$ tetrabutylammonium hexafluorophosphate as the supporting electrolyte using platinum working and auxiliary electrodes and a $\mathrm{Ag}$ pseudo-reference electrode. The electrode wires were PTFE-coated and all situated in the bulk solution inside the cavity of the spectrometer. The wires were all cut to different lengths and the PTFE removed at the bottom of each wire to allow contact with the solution, but so that no bare wires could touch each other [49]. The potentiostat (Autolab, Type II) was controlled via a PC running General Purpose Electrochemical System software, version 4.9 (Eco Chemie BV, Utrecht). EPR simulations were performed using the Bruker Win-EPR Simfonia software.

$\mathrm{RuClH}(\mathrm{CO})\left(\mathrm{P}^{i} \mathrm{Pr}_{3}\right)_{2}$ was prepared according to Ref. [50] 4-Ethynyl [2.2]paracyclophane and pseudo-para-diethynyl[2.2]paracyclophane were prepared according to Ref. [51]. The synthesis of 3,7-diethynyl-10,11-dihydro-5H-dibenzo[a,d]cycloheptene was adapted from Lambert et al. [52] with some modifications of the published procedure as given in the Supporting Information.

\subsubsection{4-( $\left.\mathrm{P}^{\mathrm{i}} \mathrm{Pr}_{3}\right)_{2}(\mathrm{CO}) \mathrm{ClRu}-\mathrm{CH}=\mathrm{CH}-[2.2$ ]paracyclophane, 1}

$73 \mathrm{mg}(0.150 \mathrm{mmol})$ of $\mathrm{RuClH}(\mathrm{CO})\left(\mathrm{P}^{i} \mathrm{Pr}_{3}\right)_{2}$ and $34 \mathrm{mg}$ $(0.145 \mathrm{mmol})$ of 4-ethynyl[2.2]paracyclophane were dissolved in dry $\mathrm{CH}_{2} \mathrm{Cl}_{2}$ under nitrogen. Soon after mixing, the solution color intensified from orange-red to deep red. Stirring was continued for $1 \mathrm{~h}$. After removal of the solvent, washing the residue with several portions of hexane and drying under dynamic vacuum, slightly impure 1 remained. This was purified from some unreacted $\mathrm{RuClH}(\mathrm{CO})\left(\mathrm{P}^{i} \mathrm{Pr}_{3}\right)_{2}$ by slowly dropping a concentrated $\mathrm{CH}_{2} \mathrm{Cl}_{2}$ solution into vigorously stirred hexane and removing the supernatant. After three repetitions and drying of the residue in oil pump vacuum, $104 \mathrm{mg}$ of the dichloromethane monosolvate $\mathbf{1} \times \mathbf{C H}_{2} \mathbf{C l}_{\mathbf{2}}$ (89\%) were obtained as a deep purple powder. ${ }^{1} \mathrm{H}$ NMR $(400.1 \mathrm{MHz}$, $\left.\mathrm{CD}_{2} \mathrm{Cl}_{2}\right): \delta 8.17\left(\mathrm{dt}, 1 \mathrm{H},{ }^{3} \mathrm{~J}_{\mathrm{HH}}=13.02 \mathrm{~Hz},{ }^{3} \mathrm{~J}_{\mathrm{P}-\mathrm{H}}=1.01 \mathrm{~Hz}, \mathrm{H}_{1}\right), 6.55$ $\left(\mathrm{dd}, 1 \mathrm{H},{ }^{3} \mathrm{HH}_{\mathrm{HH}}=7.96,{ }^{4} \mathrm{JHH}_{\mathrm{HH}}=1.84 \mathrm{~Hz}, \mathrm{H}_{12}\right), 6.53\left(\mathrm{dd}, 1 \mathrm{H}, 3_{\mathrm{HH}}=7.96\right.$, $\left.{ }^{4} J_{\mathrm{HH}}=1.84 \mathrm{~Hz}, \mathrm{H}_{15}\right), 6.48\left(\mathrm{dd}, 1 \mathrm{H},{ }^{3} \mathrm{~J}_{\mathrm{HH}}=7.76 \mathrm{~Hz},{ }^{4} \mathrm{JHH}_{\mathrm{HH}}=1.76 \mathrm{~Hz}\right.$, $\left.\mathrm{H}_{16}\right), 6.22\left(\mathrm{dd}, 1 \mathrm{H},{ }^{3} \mathrm{JHH}_{\mathrm{HH}}=7.96 \mathrm{~Hz},{ }^{4} \mathrm{~J}_{\mathrm{HH}}=1.76 \mathrm{~Hz}, \mathrm{H}_{13}\right), 6.20(\mathrm{~d}, 1 \mathrm{H}$, $\left.{ }^{3} J_{\mathrm{HH}}=7.56 \mathrm{~Hz}, \mathrm{H}_{7}\right), 6.18\left(\mathrm{~d}, 1 \mathrm{H},{ }^{3} \mathrm{~J}_{\mathrm{HH}}=1.76 \mathrm{~Hz}, \mathrm{H}_{4}\right), 6.15(\mathrm{dd}, 1 \mathrm{H}$, $\left.{ }^{3} J_{\mathrm{HH}}=7.56 \mathrm{~Hz},{ }^{4} J_{\mathrm{HH}}=1.76 \mathrm{~Hz}, \mathrm{H}_{6}\right), 6.08\left(\mathrm{dt}, 1 \mathrm{H},{ }^{3} J_{\mathrm{HH}}=13.02 \mathrm{~Hz}\right.$,

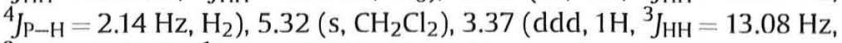
$\left.{ }^{3} J_{\mathrm{HH}}=10.10 \mathrm{~Hz},{ }_{\mathrm{HH}}=2.50 \mathrm{~Hz}, \mathrm{H}_{9}\right), 3.11-2.93\left(\mathrm{~m}, 6 \mathrm{H}, \mathrm{H}_{10}, \mathrm{H}_{17}, \mathrm{H}_{18}\right)$, $2.86\left(\mathrm{spt}, 3 \mathrm{H},{ }^{3} \mathrm{~J}_{\mathrm{HH}}=7.90 \mathrm{~Hz} \mathrm{CH}\left(\mathrm{CH}_{3}\right)_{2}\right), 2.71\left(\mathrm{~m}, 4 \mathrm{H}, \mathrm{CH}\left(\mathrm{CH}_{3}\right)_{2}, \mathrm{H}_{9^{\prime}}\right)$, 
$1.47-1.39\left(\mathrm{~m}, 18 \mathrm{H}, \mathrm{CH}\left(\mathrm{CH}_{3}\right)_{2}\right), 1.28-1.15\left(\mathrm{~m}, 18 \mathrm{H}, \mathrm{CH}\left(\mathrm{CH}_{3}\right)_{2}\right) .{ }^{13} \mathrm{C}\left\{{ }^{1} \mathrm{H}\right\}$ NMR (150.9 MHz, $\left.\mathrm{CD}_{2} \mathrm{Cl}_{2}\right): \delta 203.4\left(\mathrm{t},{ }^{2} J_{\mathrm{P}-\mathrm{C}}=13.1 \mathrm{~Hz}, \mathrm{C}_{19}\right), 150.8(\mathrm{t}$, $\left.{ }^{2} \mathrm{JP}_{\mathrm{C}} \mathrm{C}=10.6 \mathrm{~Hz}, \mathrm{C}_{1}\right), 140.0\left(\mathrm{~s}, \mathrm{C}_{11}\right), 139.9\left(\mathrm{~s}, \mathrm{C}_{14}\right), 139.7\left(\mathrm{~s}, \mathrm{C}_{5}\right), 139.5(\mathrm{~s}$, $\left.\mathrm{C}_{3}\right), 134.9\left(\mathrm{~s}, \mathrm{C}_{7}\right), 133.4\left(\mathrm{~s}, \mathrm{C}_{8}\right), 133.3\left(\mathrm{~s}, \mathrm{C}_{16}\right), 132.8\left(\mathrm{~s}, \mathrm{C}_{15}\right), 132.5(\mathrm{~s}$, $\mathrm{C}_{2}$ ), $132.4\left(\mathrm{~s}, \mathrm{C}_{13}\right), 130.9\left(\mathrm{~s}, \mathrm{C}_{12}\right), 130.7\left(\mathrm{~s}, \mathrm{C}_{4}\right), 129.0\left(\mathrm{~s}, \mathrm{C}_{6}\right), 35.8$ (s, $\left.\mathrm{C}_{17}\right), 35.7\left(\mathrm{~s}, \mathrm{C}_{18}\right), 35.1\left(\mathrm{~s}, \mathrm{C}_{10}\right), 33.5\left(\mathrm{~s}, \mathrm{C}_{9}\right), 24.5\left(\mathrm{vt}, \mathrm{JP}_{\mathrm{P}-\mathrm{C}}=15.0 \mathrm{~Hz}\right.$, $\left.\mathrm{CH}\left(\mathrm{CH}_{3}\right)_{2}\right), 20.1,20.0\left(\mathrm{~s}, \mathrm{CH}\left(\mathrm{CH}_{3}\right)_{2}\right) .{ }^{31} \mathrm{P}\left\{{ }^{1} \mathrm{H}\right\}$ NMR $(121.5 \mathrm{MHz}$, $\left.\mathrm{CD}_{2} \mathrm{Cl}_{2}\right) \delta 39.35\left(\mathrm{~d},{ }^{3} \mathrm{JPP}=411 \mathrm{~Hz}\right), 37.65\left(\mathrm{~d},{ }^{3} \mathrm{JP}_{\mathrm{PP}}=411 \mathrm{~Hz}\right)$. Anal. Calcd. for $\mathrm{C}_{38} \mathrm{H}_{61} \mathrm{Cl}_{3} \mathrm{OP}_{2} \mathrm{Ru}$ : C, 56.82; H, 7.65; Found: C, 57.21; $\mathrm{H}$, 7.63 .

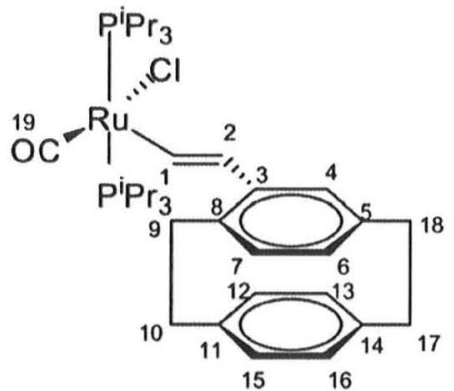

\subsubsection{Pseudo-para- $\left\{\left(\mathrm{P}^{\mathrm{i}} \mathrm{Pr}_{3}\right)_{2}(\mathrm{CO}) \mathrm{ClRu}-\mathrm{CH}=\mathrm{CH}\right\}_{2}[2.2]$}

paracyclophane, 2

$82 \mathrm{mg}(0.17 \mathrm{mmol})$ of $\mathrm{RuClH}(\mathrm{CO})\left(\mathrm{P}^{i} \mathrm{Pr}_{3}\right)_{2}$ and $21 \mathrm{mg}(0.08 \mathrm{mmol})$ of pseudo-para-diethynyl[2.2]paracyclophane were dissolved in dry $\mathrm{CH}_{2} \mathrm{Cl}_{2}$ under nitrogen and stirred at room temperature for $1 \mathrm{~h}$, whereupon the orange-red color of the hydride complex changed to deep purple. The solvent was removed and the residue was washed with several portions of n-hexane and then dried under vacuum to give $\mathbf{2}$ as a deep purple powder. Further purification was achieved by repeated (two times) precipitation of $\mathbf{2}$ by slowly adding a concentrated $\mathrm{CH}_{2} \mathrm{Cl}_{2}$ solution into vigorously stirred hexanes. $99 \mathrm{mg}$ (94\%) of the dichloromethane monosolvate were obtained after drying of the residue in vacuo. ${ }^{1} \mathrm{H}$ NMR $(300.1 \mathrm{MHz}$, $\left.\mathrm{CD}_{2} \mathrm{Cl}_{2}\right): \delta 8.12\left(\mathrm{~d}, 2 \mathrm{H},{ }^{3} \mathrm{JHH}_{\mathrm{HH}}=12.98 \mathrm{~Hz}, \mathrm{H}_{1}\right), 6.22\left(\mathrm{~s}, 2 \mathrm{H}, \mathrm{H}_{4}\right), 6.21(\mathrm{~d}$, $\left.2 \mathrm{H},{ }^{3} J_{\mathrm{HH}}=7.48 \mathrm{~Hz}, \mathrm{H}_{6}\right), 6.09\left(\mathrm{dt}, 2 \mathrm{H},{ }^{3} J_{\mathrm{HH}}=12.98 \mathrm{~Hz},{ }^{4} J_{\mathrm{HP}}=1.98 \mathrm{~Hz}\right.$ $\left.\mathrm{H}_{2}\right), 5.98\left(\mathrm{~d}, 2 \mathrm{H},{ }^{3} \mathrm{JHH}_{\mathrm{HH}}=7.48 \mathrm{~Hz}, \mathrm{H}_{7}\right), 5.32\left(\mathrm{~s}, \mathrm{CH}_{2} \mathrm{Cl}_{2}\right), 3.31$ (ddd, $2 \mathrm{H}$, $\left.{ }^{3} \mathrm{~J}_{\mathrm{HH}}=3.36 \mathrm{~Hz},{ }^{3} \mathrm{~J}_{\mathrm{HH}}=13.26 \mathrm{~Hz},{ }^{2} \mathrm{~J}_{\mathrm{HH}}=0.06 \mathrm{~Hz}, \mathrm{H}_{9}\right), 2.91-2.80(\mathrm{~m}$, $\left.10 \mathrm{H}, \mathrm{H}_{10}, \mathrm{CH}\left(\mathrm{CH}_{3}\right)_{2}\right), 2.75-2.65\left(\mathrm{~m}, 8 \mathrm{H}, \mathrm{H}_{9}, \mathrm{CH}\left(\mathrm{CH}_{3}\right)_{2}\right), 1.44-1.38$ $\left(\mathrm{m}, 36 \mathrm{H}, \mathrm{CH}\left(\mathrm{CH}_{3}\right)_{2}\right), 1.26-1.19\left(\mathrm{~m}, 36 \mathrm{H}, \mathrm{CH}\left(\mathrm{CH}_{3}\right)_{2}\right) .{ }^{13} \mathrm{C}\left\{{ }^{1} \mathrm{H}\right\}$ NMR $\left(150.9 \mathrm{MHz}, \mathrm{CD}_{2} \mathrm{Cl}_{2}\right): \delta 203.5\left(\mathrm{t},{ }^{2} \mathrm{JP}_{\mathrm{C}} \mathrm{C}=13.13 \mathrm{~Hz}, \mathrm{C}_{11}\right), 149.9(\mathrm{t}$, $\left.{ }_{\mathrm{JP}-\mathrm{C}}=10.6 \mathrm{~Hz}, \mathrm{C}_{1}\right), 139.9\left(\mathrm{~s}, \mathrm{C}_{5}\right), 139.5\left(\mathrm{~s}, \mathrm{C}_{3}\right), 133.9\left(\mathrm{~s}, \mathrm{C}_{7}\right), 133.3(\mathrm{~s}$, $\left.\mathrm{C}_{8}\right), 132.8\left(\mathrm{t},{ }^{4} \mathrm{P}-\mathrm{C}=3.0 \mathrm{~Hz}, \mathrm{C}_{2}\right), 130.0\left(\mathrm{~s}, \mathrm{C}_{4}\right), 127.1\left(\mathrm{~s}, \mathrm{C}_{6}\right), 35.0(\mathrm{~s}$, $\left.\mathrm{C}_{10}\right), 32.9$ (s, $\left.\mathrm{C}_{9}\right), 24.6,24.4$ (vt, JP-C $\left.=9.8 \mathrm{~Hz}, \mathrm{CH}\left(\mathrm{CH}_{3}\right)_{2}\right), 20.1,19.9$ (s, $\left.\mathrm{CH}\left(\mathrm{CH}_{3}\right)_{2}\right) .{ }^{31} \mathrm{P}\left\{{ }^{1} \mathrm{H}\right\} \quad \mathrm{NMR} \quad\left(121.5 \mathrm{MHz}, \quad \mathrm{CD}_{2} \mathrm{Cl}_{2}\right): 39.29$ (d, $\left.{ }^{3} J_{\mathrm{PP}}=419 \mathrm{~Hz}\right), \quad 37.58 \quad\left(\mathrm{~d}, \quad{ }^{3} \mathrm{PP}_{\mathrm{PP}}=419 \mathrm{~Hz}\right)$. Anal. Calcd. for $\mathrm{C}_{59} \mathrm{H}_{104} \mathrm{Cl}_{4} \mathrm{O}_{2} \mathrm{P}_{4} \mathrm{Ru}_{2}$ : C, 53.96; H, 7.98; Found: C, 52.82; H, 8.22.

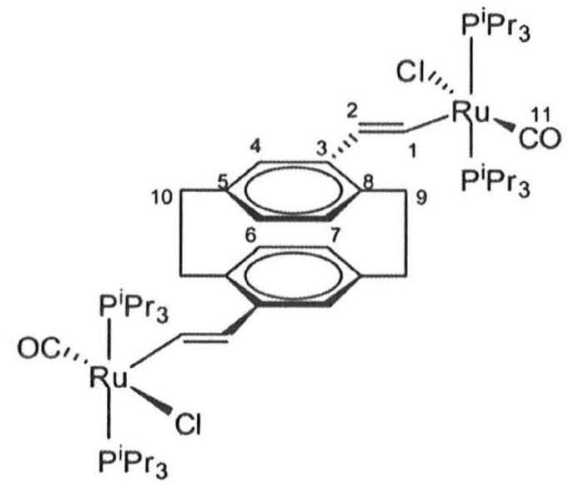

\subsection{3. $\left\{\mathrm{Ru}(\mathrm{CO}) \mathrm{Cl}\left(\mathrm{P}^{i} \mathrm{Pr}_{3}\right)_{2}\right\}_{2}$-3,7-divinyl-10,11-dihydro-5H-dibenzo} [a,d]cycloheptene, 3

$138.8 \mathrm{mg}(0.285 \mathrm{mmol})$ of $\mathrm{RuClH}(\mathrm{CO})\left(\mathrm{P}^{i} \mathrm{Pr}_{3}\right)_{2}$ and $34.5 \mathrm{mg}$ $(0.142 \mathrm{mmol})$ of 8 were dissolved in dry $\mathrm{CH}_{2} \mathrm{Cl}_{2}$ under nitrogen. The solution color rapidly intensified from orange-red to purple-red. After stirring at room temperature for $1 \mathrm{~h}$ the solvent was removed under vacuum. The purple-red residue was washed with several portions of hexane, then reprecipitated two times from a $\mathrm{CH}_{2} \mathrm{Cl}_{2}$ /hexane mixture and dried under vacuum. $171 \mathrm{mg}(92 \%)$ of the dichloromethane monosolvate were obtained. ${ }^{1} \mathrm{H}$ NMR $\left(300.1 \mathrm{MHz}, \mathrm{CD}_{2} \mathrm{Cl}_{2}\right): \delta 8.43\left(\mathrm{~d}, 2 \mathrm{H},{ }^{3}{ }_{\mathrm{HH}}=13.44 \mathrm{~Hz}, \mathrm{H}_{1}\right), 6.90(\mathrm{~d}, 2 \mathrm{H}$ $\left.{ }^{3} J_{\mathrm{HH}}=7.68 \mathrm{~Hz}, \mathrm{H}_{5}\right), 6.82\left(\mathrm{dd}, 2 \mathrm{H},{ }^{3} \mathrm{~J}_{\mathrm{HH}}=7.68 \mathrm{~Hz},{ }^{4} \mathrm{~J}_{\mathrm{HH}}=1.71 \mathrm{~Hz}, \mathrm{H}_{4}\right)$, $6.79\left(\mathrm{~d}, 2 \mathrm{H},{ }^{4} \mathrm{~J}_{\mathrm{HH}}=1.71 \mathrm{~Hz}, \mathrm{H}_{8}\right), 5.90\left(\mathrm{dt}, 2 \mathrm{H},{ }^{3} \mathrm{~J}_{\mathrm{HH}}=13.44 \mathrm{~Hz}\right.$, $\left.{ }^{4} J_{\mathrm{P}-\mathrm{H}}=2.05 \mathrm{~Hz}, \mathrm{H}_{2}\right), 3.91\left(\mathrm{~s}, 2 \mathrm{H}, \mathrm{H}_{10}\right), 3.02\left(\mathrm{~s}, 4 \mathrm{H}, \mathrm{H}_{9}\right), 2.80-2.65(\mathrm{~m}$, $\left.12 \mathrm{H}, \mathrm{CH}\left(\mathrm{CH}_{3}\right)_{2}\right), 1.33-1.21\left(\mathrm{~m}, 72 \mathrm{H}, \mathrm{CH}\left(\mathrm{CH}_{3}\right)_{2}\right) .{ }^{13} \mathrm{C}\left\{{ }^{1} \mathrm{H}\right\} \quad \mathrm{NMR}$ $\left(150.9 \mathrm{MHz}, \mathrm{CD}_{2} \mathrm{Cl}_{2}\right): \delta 203.4\left(\mathrm{t},{ }^{2} J_{\mathrm{P}-\mathrm{C}}=13.2 \mathrm{~Hz}, \mathrm{C}_{11}\right), 149.0(\mathrm{t}$, $\left.{ }^{2} J_{\mathrm{P}-\mathrm{C}}=11.1 \mathrm{~Hz}, \mathrm{C}_{1}\right), 139.5\left(\mathrm{~s}, \mathrm{C}_{7}\right), 137.1\left(\mathrm{~s}, \mathrm{C}_{3}\right), 135.2\left(\mathrm{~s}, \mathrm{C}_{6}\right), 134.4(\mathrm{~s}$, $\left.\mathrm{C}_{2}\right), 129.9\left(\mathrm{~s}, \mathrm{C}_{5}\right), 125.0\left(\mathrm{~s}, \mathrm{C}_{8}\right), 122.3\left(\mathrm{~s}, \mathrm{C}_{4}\right), 41.5\left(\mathrm{~s}, \mathrm{C}_{10}\right), 32.5\left(\mathrm{~s}, \mathrm{C}_{9}\right)$, $24.8\left(\mathrm{vt}, \mathrm{JP}-\mathrm{C}=9.9 \mathrm{~Hz}, \mathrm{CH}\left(\mathrm{CH}_{3}\right)_{2}\right), 20.1,19.9\left(\mathrm{~s}, \mathrm{CH}\left(\mathrm{CH}_{3}\right)_{2}\right) .{ }^{31} \mathrm{P}\left\{{ }^{1} \mathrm{H}\right\}$ NMR $\left(121.5 \mathrm{MHz}, \quad \mathrm{CD}_{2} \mathrm{Cl}_{2}\right) \quad \delta \quad 38.41$ (s). Anal. Calcd. for $\mathrm{C}_{58} \mathrm{H}_{102} \mathrm{Cl}_{4} \mathrm{O}_{2} \mathrm{P}_{4} \mathrm{Ru}_{2}: \mathrm{C}, 53.61 ; \mathrm{H}, 7.91$; Found: $\mathrm{C}, 53.14 ; \mathrm{H}, 8.04$.

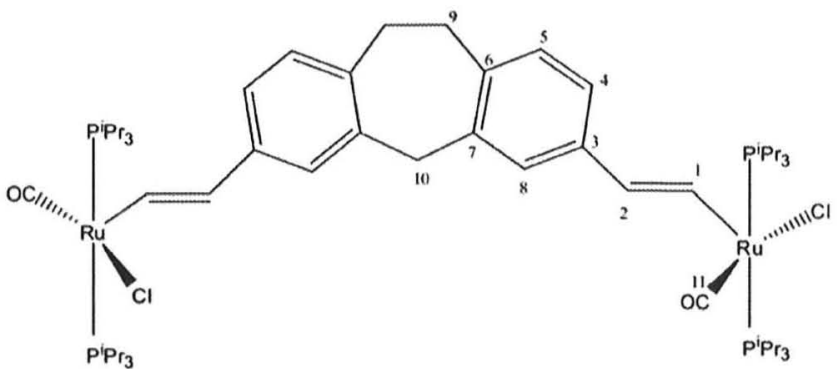

2.1.4. X-ray structure determination of complex 2

Geometry and intensity data were collected on an Oxford Diffraction Gemini Ultra CCD diffractometer with multilayer optics and with a $\mathrm{Cu} \mathrm{K} \alpha(\lambda=1.54184 \AA$, graphite monochromator $)$ radiation source. The data were collected at $123 \mathrm{~K}$ using an Oxford Diffraction Cryojet Cooler. The structure was solved by direct methods (SIR-97) and refined by full-matrix anisotropic least squares (SHELXL97). The H-atoms were calculated geometrically and a riding model was used during the refinement process.

\subsection{Quantum chemical calculations}

The ground-state electronic structures were calculated by density functional theory (DFT) methods using the Gaussian 09 [53] and ADF $[54,55]$ program packages. In order to reduce computational time to a reasonable limit, $\mathrm{P}^{i} \mathrm{Pr}_{3}$ ligands were replaced by $\mathrm{PMe}_{3}$. Models for experimental systems $\mathbf{1}, \mathbf{2}$ and $\mathbf{3}$ are denoted as $1^{\mathrm{Me}}, 2^{\mathrm{Me}}$ and $3^{\mathrm{Me}}$. Quantum chemical studies were performed without any symmetry constraints for all accessible oxidation states. Open shell systems were calculated by the unrestricted Kohn-Sham approach (UKS). Geometry optimization followed by vibrational analysis was made either in vacuum or in solvent media.

The quasirelativistic effective core pseudopotentials and the corresponding optimized set of basis functions for Ru [56] and 6$31 \mathrm{G}^{*}$ polarized double- $\zeta$ basis sets [57] for the remaining atoms were employed together with the Perdew, Burke, Ernzerhof exchange and correlation functional (PBE0) $[58,59]$. The Meta GGA functional M05-2x containing larger admixture of Hartree-Fock (HF) exchange was used for comparison [60]. Solvent effects were 
described by the polarizable conductor continuum model (CPCM) [61].

The g-tensor (calculated by ADF) was obtained from a spinnonpolarized wave function after incorporating the spin-orbit (SO) coupling by first-order perturbation theory from the ZORA Hamiltonian in the presence of a time-independent magnetic field $[62,63]$. Within ADF, Slater type orbital (STO) basis sets of triple- $\xi$ quality with two polarization functions for Ru and one polarization function for remaining atoms were employed. The inner shells were represented by a frozen core approximation, viz. $1 \mathrm{~s}$ for $\mathrm{C}, \mathrm{N}, \mathrm{O}$, $1 \mathrm{~s}-2 \mathrm{p}$ for $\mathrm{P}, \mathrm{Cl}$ and $1 \mathrm{~s}-3 \mathrm{~d}$ for Ru were kept frozen. The calculations were done with the functional including Becke's gradient correction [64] to the local exchange expression in conjunction with Perdew's gradient correction [65] to the local correlation (ADF/BP). The scalar relativistic (SR) zero order regular approximation (ZORA) [66] was used within this study.

\section{Results}

\section{1. [2.2]Paracyclophane complexes $\mathbf{1}$ and $\mathbf{2}$}

The mono- and diruthenium [2.2]paracylophane complexes $\mathbf{1}$ and $\mathbf{2}$ of Chart 1 were prepared by hydroruthenation of 4-ethynyl [2.2]paracyclophane or of pseudo-para-diethynyl[2.2]paracyclophane with $\mathrm{RuClH}(\mathrm{CO})\left(\mathrm{P}^{i} \mathrm{Pr}_{3}\right)_{2}$ and accordingly characterized by multinuclear NMR and IR spectroscopy. ${ }^{1} \mathrm{H}$ and ${ }^{13} \mathrm{C}$ NMR spectra of the unsymmetrically substituted monoruthenium complex $\mathbf{1}$ feature separate resonances for every individual carbon and hydrogen atom which could be assigned on the basis of one- and two-dimensional NMR spectra and by application of HMBC and HSQC pulse sequences. Of note is a slight high-field shift of the bridgehead carbon atoms that link the benzene ring to the ethylene straps for the more electron-rich, vinyl ruthenium substituted deck when compared to the unsubstituted one. The vinyl ruthenium moiety gives rise to ${ }^{1} \mathrm{H}$ signals at $8.17(\mathrm{Ru}-\mathrm{CH})$ and $6.08 \mathrm{ppm}$ $(\mathrm{Ru}-\mathrm{CH}=\mathrm{CH})$ which are both split into triplets of doublets by ${ }^{3} \mathrm{JH}_{\mathrm{H}-\mathrm{H}}$ $\left(J=13.0 \mathrm{~Hz}\right.$ ) and ${ }^{3} \mathrm{~J}_{\mathrm{H}-\mathrm{P}}$ or ${ }^{4} \mathrm{~J}_{\mathrm{H}-\mathrm{P}}$ couplings of 1.0 or $2.1 \mathrm{~Hz}$, respectively, and ${ }^{13} \mathrm{C}$ NMR signals at $150.8\left({ }^{2} J_{\mathrm{P}-\mathrm{C}}=10.6 \mathrm{~Hz}, \mathrm{Ru}-\mathrm{CH}\right)$ and $132.5 \mathrm{ppm}(\mathrm{Ru}-\mathrm{CH}=\mathrm{CH})$ for the vinyl group as well as the appropriate resonance signals of the $\mathrm{P}^{i} \mathrm{Pr}_{3}$ ligands. The low symmetry of the complexes ( $C_{1}$ for complex $\mathbf{1}, C_{2 \mathrm{~h}}$ for complex 2 ) renders the two $\mathrm{P}^{i} \mathrm{Pr}_{3}$ ligands at each metal atom chemically and magnetically inequivalent such that two closely spaced doublet signals with coupling constants of $411 \mathrm{~Hz}$ (1) or $418 \mathrm{~Hz}(2)$ and a pronounced roof effect are observed. The $\nu(\mathrm{CO})$ band of the $\mathrm{Ru}(\mathrm{CO})$ subunit is observed as a strong resonance at $1910 \mathrm{~cm}-1$ while weaker bands at 1553 and $1544 \mathrm{~cm}^{-1}$ are probably of $\nu(C=C)$ parentage. Simpler spectra are observed for dinuclear $\mathbf{2}$ in keeping with the presence of an inversion center with almost identical NMR shifts for the ${ }^{1} \mathrm{H}$ and ${ }^{13} \mathrm{C}$ NMR vinyl resonances as were observed in $\mathbf{1}$. Thus, the vinyl protons resonate at 8.12 and $6.09 \mathrm{ppm}\left({ }^{3} \mathrm{JH}_{\mathrm{H}-\mathrm{H}}=13.0 \mathrm{~Hz}\right)$ while the appropriate carbon resonances are observed at 149.9 $\left({ }^{2} \mathrm{JP}-\mathrm{C}=10.6 \mathrm{~Hz}\right)$ and at $132.8 \mathrm{ppm}\left({ }^{3} \mathrm{JP}-\mathrm{C}=3.0 \mathrm{~Hz}\right)$. Just like for $\mathbf{1}$, the IR spectra feature diagnostic bands at 1909, 1555 and $1544 \mathrm{~cm}^{-1}$. Again, two closely spaced doublets with $J_{\mathrm{P}-\mathrm{P}}=419 \mathrm{~Hz}$ and a pronounced roof effect were observed in the ${ }^{31} \mathrm{P}$ NMR spectrum.

Deep red rod-shaped crystals of the $\mathrm{CH}_{2} \mathrm{Cl}_{2}$ bis(solvate) of pseudo-para-divinyl[2.2]paracyclophane-bridged diruthenium complex 2 were obtained from concentrated solutions in $\mathrm{CH}_{2} \mathrm{Cl}_{2}$ and subjected to an X-ray diffraction study. The results are illustrated in Fig. 1 and Table 1. Details to the data collection and structure refinement and a more complete listing of bond lengths and angles can be found in Tables S4 and S5 of the Supporting Information. The structure data suggest some degree of disorder

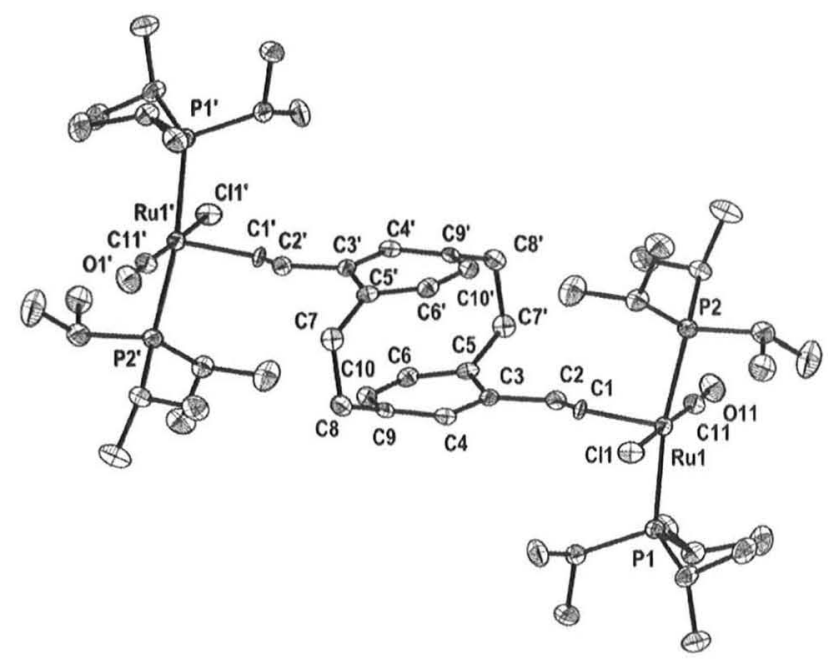

Fig. 1. ORTEP showing the crystallographically determined structure of complex 2 Ellipsoids are drawn at a $50 \%$ probability level.

between the $\mathrm{CO}$ and $\mathrm{Cl}$ ligands, which, however, could not be resolved. Structural parameters of the central aromatic core strongly resemble those of other [2.2]paracyclophane derivatives and, particularly, those of 2,2-dibromovinyl-4-[2.2]paracyclophane [51] and 4,12-bis(2,2-dibromovinyl)[2.2]paracyclophane [67]. Ring strain imposed by the ethylene straps induces an opening of the corresponding $\mathrm{C}-\mathrm{C}-\mathrm{C}$ angles at the aliphatic carbon atoms to $112.9(4)$ and $113.1(4)^{\circ}$ and a boat like distortion of each phenyl deck. This results in a smaller separation between the bridgehead carbon atoms $C(5) \cdots C\left(9^{\prime}\right)$ of $2.773 \AA$ as opposed to the distance between the mean planes through the remaining carbon atoms of $3.065 \AA$. Interplanar angles between the planes through carbon atoms $C(3), C(5), C(6)$ or atoms $(C 4), C(9), C(10)$ forming the bow and rear of the boat and the mean plane through the non-bridged carbon atoms $C(3), C(4), C(6)$ and $C(10)$ amount to $12.1^{\circ}$. Comparable values of $10.9-14.5^{\circ}$ are observed for 2,2-dibromovinyl-4[2.2]paracyclophane [51] while the respective values for 4,12bis(2,2-dibromovinyl)[2.2]paracyclophane are 7.0 to $8.0^{\circ}$ [67], with a separation of $3.075 \AA$ between the decks. In keeping with similar five-coordinated vinyl ruthenium complexes [68-75] the ruthenium atoms adopt a square pyramidal coordination geometry

Table 1

The DFT/PBEO calculated symmetry averaged bond lengths $(\AA)$ and angles $\left(^{\circ}\right)$ for model $2^{\mathrm{Me}}$ complex and the comparison with experimental structural parameters.

\begin{tabular}{lcl}
\hline & $\mathbf{2}^{\mathrm{Me}}[\AA]$ & $\mathbf{2}[\AA]$ \\
\hline $\mathrm{Ru}-\mathrm{C} 11$ & 1.815 & $1.828(5)$ \\
$\mathrm{Ru}-\mathrm{Cl} 1$ & 2.423 & $2.4432(11)$ \\
$\mathrm{Ru}-\mathrm{C1}$ & 1.990 & $2.006(4)$ \\
$\mathrm{Ru}-\mathrm{P1}$ & 2.354 & $2.4080(12)$ \\
$\mathrm{Ru}-\mathrm{P2}$ & 2.354 & $2.4063(12)$ \\
$\mathrm{Ru}-\mathrm{Cl}$ & 2.423 & $2.4432(11)$ \\
$\mathrm{C} 1-\mathrm{C2}$ & 1.348 & $1.322(6)$ \\
$\mathrm{C} 2-\mathrm{C3}$ & 1.472 & $1.482(6)$ \\
$\mathrm{C} 3-\mathrm{C4}$ & 1.405 & $1.413(6)$ \\
$\mathrm{C} 3-\mathrm{C5}$ & 1.416 & $1.415(6)$ \\
$\mathrm{C} 4-\mathrm{C9}$ & 1.394 & $1.380(7)$ \\
$\mathrm{C} 9-\mathrm{C} 8$ & 1.508 & $1.510(7)$ \\
$\mathrm{C} 8-\mathrm{C} 7$ & 1.593 & $1.592(7)$ \\
$\mathrm{C} 5-\mathrm{C9}$ & 2.782 & 2.773 \\
Stacking distance & 3.072 & 3.065 \\
Ru-C1-C2 & 134.0 & $134.5(3)$ \\
$\mathrm{C} 1-\mathrm{C2}-\mathrm{C} 3$ & 126.9 & $125.5(4)$ \\
\hline
\end{tabular}


with the vinyl substituent in the apical position and trans angles of $175.0(1)\left(\mathrm{C}(11)-\mathrm{Ru}-\mathrm{C}(1)\right.$ and $170.31(4)^{\circ}(\mathrm{P}(1)-\mathrm{Ru}-\mathrm{P}(2))$ as well as cis-angles in the range of $88.04(4)\left(\mathrm{Cl}(1)-\mathrm{Ru}-\mathrm{P}(2)\right.$ to $99.05(13)^{\circ}$ $(\mathrm{P}(2)-\mathrm{Ru}-\mathrm{C}(1))$. This results from a $0.137 \AA$ displacement of the metal atom from the basal plane towards the apical vinyl ligand. The vinyl group itself has a $C=C$ bond length $C(1)-C(2)$ of $1.322(6)$ $\AA$ and suffers some opening of the $R u(1)-C(1)-C(2)$ angle to $134.5(3)^{\circ}$ when compared to the $C(1)-C(2)-C(3)$ angle of $125.5(4)^{\circ}$. Torsional angles $\mathrm{Ru}(1)-C(1)-C(2)-C(3)$ of $-170.0(4)^{\circ}$ and $C(1)-$ $C(2)-C(3)-C(4)$ of $12.6(7)^{\circ}$ signal efficient conjugation throughout the entire $\mathrm{Ru}-\mathrm{CH}=\mathrm{CH}-\mathrm{Ph}$ moiety as it is routinely found in trans configured vinyl ruthenium complexes bearing an aryl substituent. This is in stark contrast to the aforementioned 4-(2,2dibromovinyl)[2.2]paracyclophane and 4,12-bis(2,2-dibromovinyl) [2.2]paracyclophane where steric hindrance between the cisdisposed bromine atom and the adjacent proton of the arene deck prevent a coplanar arrangement with torsional angles $C_{\text {arene }}=$ $\mathrm{C}_{\text {arene }}-\mathrm{C}_{\text {vinyl }}=\mathrm{C}_{\text {vinyl }}$ of ca. $50^{\circ}$. Geometry optimization by density functional theory (DFT, Gaussian 09 and ADF) on the simplified model complex $2^{\mathrm{Me}}$ with the $\mathrm{P}^{\mathrm{i}} \mathrm{Pr}_{3}$ ligands replaced by $\mathrm{PMe}_{3}$ leads to a structure close to the experimental one as is shown by the comparison in Table 1. Bond lengths are reproduced within $0.02 \AA$, and the calculated $\mathrm{C} 5 \cdots \mathrm{Cg}^{\prime}$ distance of $2.782 \AA$ and the mean distance of $3.072 \AA$ between the $\mathrm{C} 3-\mathrm{C} 4-\mathrm{C} 6-\mathrm{C} 10$ and C3'-C4'-C6'-C10' planes are in good agreement with experimental separations of $2.773 \AA$ and $3.065 \AA$. A graphical representation of the calculated structure is provided in Figure $\mathrm{S} 6$ of the Supporting Information.

Individual molecules of $\mathbf{2}$ arrange into stepped stacks that run along the diagonal of the $a b$-plane. The bulky $\mathrm{P}^{i} \mathrm{Pr}_{3}$ ligands induce a lateral shift of individual molecules residing in parallel planes and suppress any additional $\pi$-stacking interactions between them. Hydrogen bonding interactions of 2.726 and $2.818 \AA$ are observed between the ruthenium bonded $\mathrm{Cl}(1)$ atom and one hydrogen atom of each cocrystallized $\mathrm{CH}_{2} \mathrm{Cl}_{2}$ solvate molecule which occupy voids in between the stacks (see Figure $\mathrm{S} 1$ of the Supporting Information).

Voltammetric studies on complex 1 reveal the presence of one chemically and electrochemically reversible oxidation at $0.165 \mathrm{~V}$ against the ferrocene/ferrocenium standard which is followed by a chemically irreversible second oxidation process at $0.92 \mathrm{~V}$ (Fig. 2 , Table 2). These results are in full agreement with our observations on the parent styryl complex $\mathrm{RuCl}(\mathrm{CH}=\mathrm{CHPh})(\mathrm{CO})\left(\mathrm{P}^{i} \mathrm{Pr}_{3}\right)_{2}$ [74]. In dinuclear 2, however, two consecutive, reversible one-electron waves are observed at 0.125 and $0.335 \mathrm{~V}$ while any additional

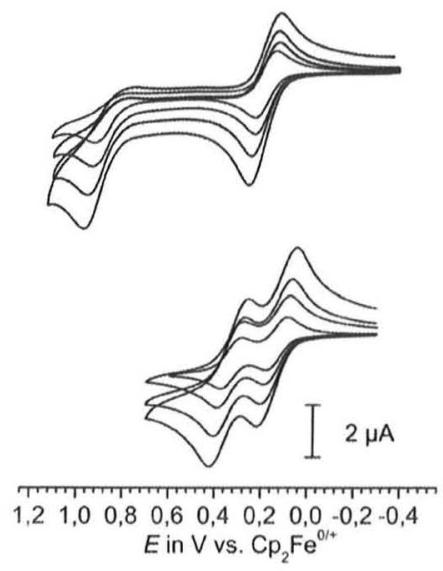

Fig. 2. Cyclic voltammetry measurements on complexes $\mathbf{1}$ (top) and $\mathbf{2}$ (bottom) in $\mathrm{CH}_{2} \mathrm{Cl}_{2} / \mathrm{NBu}_{4} \mathrm{PF}_{6}(0.1 \mathrm{M})$ at r.t. and at sweep rates of $50,100,200$, and $500 \mathrm{mV} / \mathrm{s}$.
Table 2

Electrochemical data for complexes $\mathbf{1}-\mathbf{3}\left(\mathrm{CH}_{2} \mathrm{Cl}_{2} / 0.1 \mathrm{M} \mathrm{NBu}_{4} \mathrm{PF}\right.$, r.t. $)$.

\begin{tabular}{lllll}
\hline Complex & $E_{1 / 2}^{0 / 1}[\mathrm{~V}]( \pm 3 \mathrm{mV})$ & $E_{1 / 2}^{+/ 2+}[\mathrm{V}]( \pm 3 \mathrm{mV})$ & $\Delta E_{1 / 2}[\mathrm{mV}]$ & $K_{\text {comp }}$ \\
\hline $\mathbf{1}$ & 0.165 & $0.92^{\mathrm{a}}$ & n. a. & n. a. \\
$\mathbf{2}$ & 0.125 & 0.335 & $0.210( \pm 3)$ & 4100 \\
$\mathbf{3}$ & 0.184 & 0.289 & $0.105( \pm 3)$ & 64 \\
\hline a Peak potential of an irreversible peak at $v=0.1 \mathrm{~V} / \mathrm{s}$. & &
\end{tabular}

higher oxidation processes are shifted outside the accessible potential window (Fig. 2). The appearance of two separate waves in the $100-400 \mathrm{mV}$ range instead of one suggests stepwise oxidation of the redox-active electron-rich styryl ruthenium moieties. The potential splitting and lowering of the first oxidation potential in $\mathbf{2}$ with respect to $\mathbf{1}$ provide first pieces of evidence for electronic interaction between them but no quantitative measure for its strength. Differences of redox potentials for stepwise electron transfer in systems with two identical, interlinked redox sites are subject to several contributions other than the "electronic coupling", in particular solvation energy changes and ion pairing [76-80]. We nevertheless note that the half-wave potential separation in $\mathbf{2}$ is considerably larger as that found in Akita's $\mathrm{Cp}^{*} \mathrm{Fe}$ (dppe) capped diiron pseudo-meta-diethynyl[2.2]paracyclophane complex $\left(\mathrm{Cp}^{*}=\eta^{5}-\mathrm{C}_{5} \mathrm{Me}_{5}\right.$, dppe $=1,2-\mathrm{Ph}_{2} \mathrm{PC}_{2} \mathrm{H}_{4} \mathrm{PPh}_{2}$, $\Delta E_{1 / 2}=100 \mathrm{mV}$ ) [28] and in Connick's pseudo-para-bis(picolinaldimino)-[2.2]paracyclophane-bridged dirhenium complexes $\left(\Delta E_{1 / 2}=80 \mathrm{mV}\right)[20]$

In search of more direct measures of the electronic coupling we generated radical cation $2^{+}$by electrolysis inside a transparent thin-layer cell and compared its spectroscopic properties to those of its mononuclear counterpart $\mathbf{1}^{+}$. The latter serves as a benchmark system of a complex closely related to $\mathbf{2}$ without electronic interactions with another styryl ruthenium subunit. Oxidation of complex 1 under IR monitoring resulted in a $57 \mathrm{~cm}^{-1}$ blue shift of the $\mathrm{Ru}(\mathrm{CO})$ stretch from 1910 to $1967 \mathrm{~cm}^{-1}$ and the appearance of several new $C=C$ bands in the $1640-1520 \mathrm{~cm}^{-1}$ region which are characteristic of oxidized styryl ruthenium complexes (Fig. 3) [81]. The rather modest magnitude of the $\nu(\mathrm{CO})$ shift for the metalbonded carbonyl ligand is a consequence of the strong ligand contribution to the oxidation of styryl-type complexes like $\mathbf{1}$ and closely resembles our observations for the $[\mathrm{RuCl}(\mathrm{CH}=$ CHPh $\left.)(\mathrm{CO})\left(\mathrm{P}^{\mathrm{i}} \mathrm{Pr}_{3}\right)_{2}\right]^{0 / \cdot+}$ pair [74]. Such behavior contrasts to metal based redox processes where $\nu(\mathrm{CO})$ shifts in the range of $120-150 \mathrm{~cm}^{-1}$ are expected [82-84]. Performing the same experiment under UV/Vis/NIR monitoring induces the growth of new bands with deconvoluted peak positions at 778, 706, 469 and $437 \mathrm{~nm}$ that are typical of the oxidized styryl ruthenium

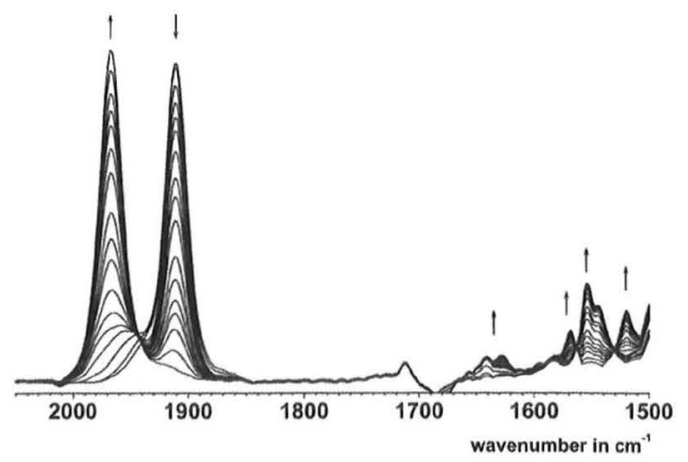

Fig. 3. Changes in the IR spectra upon the first oxidation of complex $1\left(1,2-\mathrm{C}_{2} \mathrm{H}_{4} \mathrm{Cl}_{2}\right)$ $\mathrm{NBu}_{4} \mathrm{PF}_{6}(0.2 \mathrm{M})$ at r.t.). 


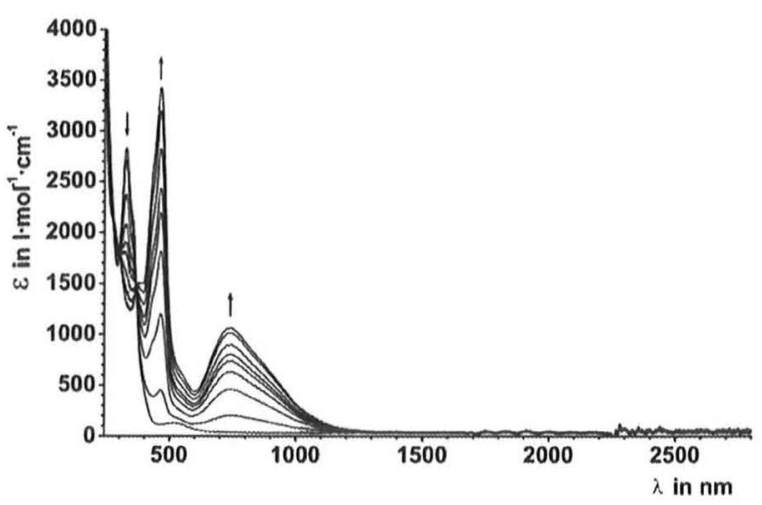

Fig. 4. Changes in the UV/Vis/NIR spectra upon the first oxidation of complex 1 (1,2$\mathrm{C}_{2} \mathrm{H}_{4} \mathrm{Cl}_{2} / \mathrm{NBu}_{4} \mathrm{PF}_{6}(0.2 \mathrm{M})$ at r.t.).

chromophore (Fig. 4) $[81,85,86]$. With reference to earlier work on pyrimidinedione appended derivatives [73] we assign these absorptions as a $\pi \rightarrow \pi^{*}$ transition of the $\{\mathrm{Ru}(\mathrm{CH}=\mathrm{CHPh})\}^{+}$ subunit and metal $\rightarrow$ styryl $^{*}{ }^{+}$charge-transfer excitations, respectively. All bands are red-shifted when compared to $[\mathrm{RuCl}(\mathrm{CH}=$ $\left.\mathrm{CHPh})(\mathrm{CO})\left(\mathrm{P}^{i} \mathrm{Pr}_{3}\right)_{2}\right]^{\cdot+}\left[{ }^{\circ 4}\right]$. The maintenance of isosbestic points throughout the measurements and the recovery of the spectra of the parent neutral after a full oxidation/reduction cycle indicate that $\mathbf{1}^{++}$is stable on the longer electrolysis timescale.

As is expected on the basis of its voltammograms, oxidation of complex 2 occurs as two separate steps with absorptions of the intermediate mixed-valent radical cation $2^{+}$clearly distinct from those of neutral 2 and fully oxidized $\mathbf{2}^{2+}$. In IR spectroelectrochemistry the single CO band of 2 at $1909 \mathrm{~cm}^{-1}$ develops into a two band pattern with separate absorptions at 1912 and $1962 \mathrm{~cm}^{-1}$ (Fig. 5). This means that, in the radical cation state, the two vinylRu(CO) subunits differ with respect to their intrinsic electron densities. Of particular note is the growth of a broad featureless band peaking at ca. $5700 \mathrm{~cm}^{-1}$ that envelopes the entire

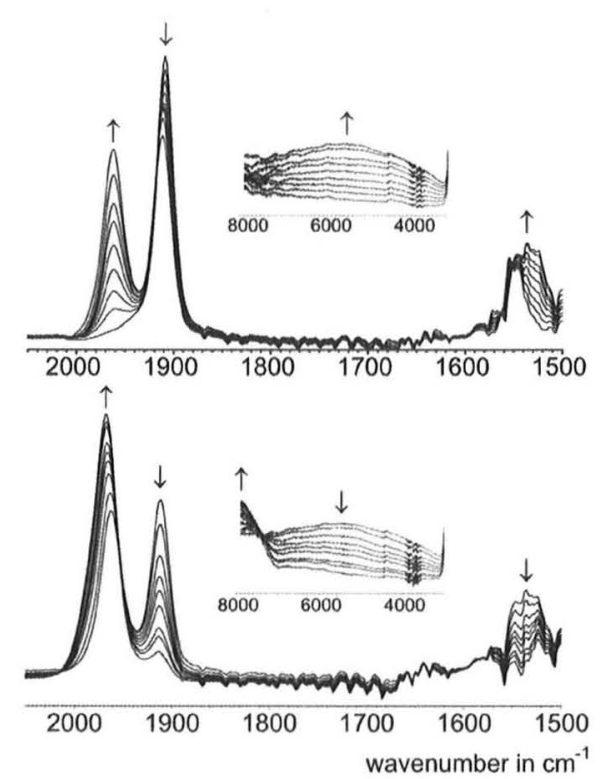

Fig. 5. Changes in the IR spectra upon the first (top) and second (bottom) oxidation of complex $2\left(1,2-\mathrm{C}_{2} \mathrm{H}_{4} \mathrm{Cl}_{2} / \mathrm{NBu}_{4} \mathrm{PF}_{6}(0.2 \mathrm{M})\right.$ at r.t). Insert: Range from 3000 to $8000 \mathrm{~cm}^{-1}$ showing the growth and the collapse of the IVCT transition of the intermediate radical cation $2^{+}$. spectroscopic regime between $3000 \mathrm{~cm}^{-1}$ and the high-energy limit of our detector (see insert of Fig. 5). Red-shifts of the $\nu(\mathrm{C}=\mathrm{C})$ absorptions of the vinyl and the arene groups are also observed. Further oxidation to dicationic $\mathbf{2}^{2+}$ restores the one-band $\nu(\mathrm{CO})$ pattern with the corresponding band peaking at $1969 \mathrm{~cm}^{-1}$ and causes complete bleaching of the broad feature of $\mathbf{2}^{\cdot+}$ at $5700 \mathrm{~cm}^{-1}$ (see insert of Fig. 5). This latter conspicuous feature is also observed to grow under UV/Vis/NIR monitoring of the first oxidation with a better defined maximum at $1828 \mathrm{~nm}\left(5470 \mathrm{~cm}^{-1}\right)$. Other bands of $\mathbf{2}^{++}$resemble those of its mononuclear counterpart $\mathbf{1}^{++}$with a broad structured feature near $700 \mathrm{~nm}$ whose low-energy shoulder deconvolutes into a separate peak at $897 \mathrm{~nm}$ and a structured band with peaks at 464,426 and $397 \mathrm{~nm}$. Full oxidation to $2^{2+}$ again causes the disappearance of the characteristic $1828 \mathrm{~nm}$ band while the other Vis/NIR absorptions of $\mathbf{2}^{++}$intensify and red-shift. Thus, a new composite band with deconvoluted peaks at 1120, 903 and $730 \mathrm{~nm}$ is observed. The band near $450 \mathrm{~nm}$ also intensifies with some loss of fine structure (Fig. 6). Nevertheless, separate maxima at 457,430 and $388 \mathrm{~nm}$ are identified upon deconvolution. Table 3 collects spectroscopic data for $\mathbf{1}$ and $\mathbf{2}$ in every accessible oxidation state.

Shifts of CO stretching frequencies were interpreted by quantum chemistry. In vacuo DFT calculations with the PBE0 functional strongly underestimate the splitting of $\mathrm{CO}$ frequencies in the radical cation of diruthenium complex $2^{\text {Me }}$. This is in keeping with the well-known fact that calculations with standard DFT functionals frequently overestimate electron density delocalization. Recently it was shown that larger admixture of HF exchange and/or the inclusion of solvation effects leads to qualitatively correct descriptions of electron delocalization in mixed-valent systems [86-89]. After inclusion of CPCM solvent correction the calculated sequence of $\mathrm{CO}$ frequencies listed in Table 4 reproduces the experimental data reasonably well. In the case of radical cation $2^{\mathrm{Me} \cdot+}$ with $\mathrm{P}^{\mathrm{i}} \mathrm{Pr}_{3}$
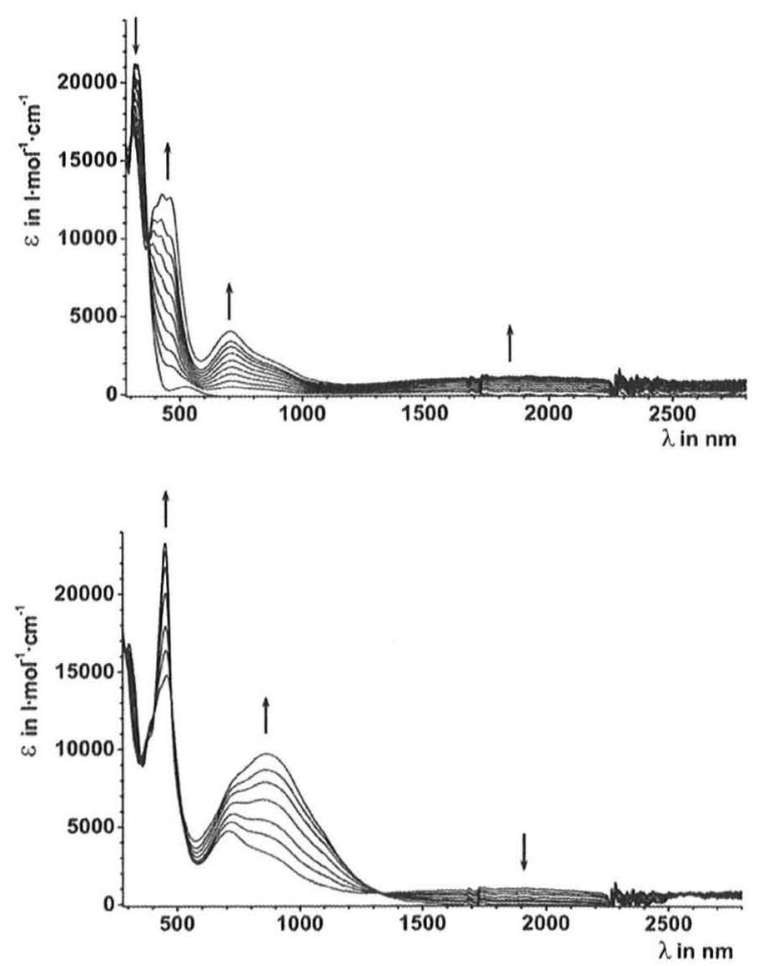

Fig. 6. Changes in the UV/Vis/NIR spectra upon the first (top) and second (bottom) oxidation of complex $2\left(1,2-\mathrm{C}_{2} \mathrm{H}_{4} \mathrm{Cl}_{2} / \mathrm{NBu}_{4} \mathrm{PF}_{6}(0.2 \mathrm{M})\right.$ at r.t.) 
Table 3

IR and UV/Vis/NIR-spectroscopic data for $\mathbf{1}^{+1^{+}}, \mathbf{2}, \mathbf{2}^{+}, \mathbf{2}^{2+}, \mathbf{3}, 3^{+}$and $3^{2+}$ in $1,2-$ $\mathrm{C}_{2} \mathrm{H}_{4} \mathrm{Cl}_{2} / \mathrm{NBu}_{4} \mathrm{PF}_{6}(0.2 \mathrm{M})$

\begin{tabular}{|c|c|c|}
\hline Complex & $\mathrm{IR} \nu\left[\mathrm{cm}^{-1}\right]$ & 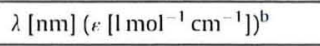 \\
\hline 1 & $\begin{array}{l}\text { 1910(s), 1553(m), 1544(m), } \\
\text { 1483(s), 1472(s), 1463(s), } \\
\text { 1382(s), 1267(s), 1165(w), } \\
\text { 1150(w), } 1107(\mathrm{w}), 1091(\mathrm{w}) \\
\text { 1064(w), 1056(w), 1030(m) }\end{array}$ & $\begin{array}{l}515 \text { (140), } 353 \text { (sh, 2100), } \\
362 \text { (2840), } 263 \text { (sh, 2700), } \\
238 \text { (sh, 5400), } 218 \text { (8600) }\end{array}$ \\
\hline $1^{++}$ & $\begin{array}{l}\text { 1967(s), } 1641(w), 1628(w) \\
1568(w), 1520(w), 1483(s) \\
1472(s), 1463(s), 1382(\mathrm{~m}) \\
1267(w), 1154(w), 1107(w) \\
1091(w), 1061(w), 1030(\mathrm{~m})\end{array}$ & $\begin{array}{l}735 \text { (1070), } 540 \text { (sh, 640), } \\
466 \text { (3430), } 434 \text { (sh, 2650), } \\
381 \text { (1500), } 274 \text { (2170), } \\
213 \text { (8600) }\end{array}$ \\
\hline 2 & $\begin{array}{l}\text { 1909, 1555(m), 1544(m), } \\
\text { 1483(s), 1471(s), 1461(s), } \\
\text { 1383(m), 1169(w), 1148(w). } \\
1105(w), 1087(w), 1061(w)\end{array}$ & $\begin{array}{l}519(660), 328(21,200), \\
243(\text { sh, 29,000) }\end{array}$ \\
\hline $2^{+}$ & $\begin{array}{l}5680,{ }^{d} 1912,1962,1571(\mathrm{w}) \\
\text { 1546(m), 1537(m), 1530(m), } \\
\text { 1482(s), 1471(s), 1403(m), } \\
\text { 1384(m), 1181(w), 1169(w), } \\
\text { 1148(w), 1105(w), 1087(w), } \\
\text { 1061(w), 1030(w) }\end{array}$ & $\begin{array}{l}1828(1100), 897(\mathrm{sh}, 2000) \\
700(4000), 461(12,700) \\
429(13,000), 397(12,000) \\
308(17,000)\end{array}$ \\
\hline $2^{2+}$ & $\begin{array}{l}\text { 1969, 1525(w), 1384(m), } \\
1484(\mathrm{~m}), 1467(\mathrm{~m}), 1156(\mathrm{~m}) \\
1090(\mathrm{w}), 1061(\mathrm{~m})\end{array}$ & $\begin{array}{l}1120 \text { (sh, } 4700), 903 \text { (9800), } \\
730 \text { (sh, 8200), } 610(4300) \\
450(23,500), 388 \text { (sh, 2560), } \\
271(18,000)\end{array}$ \\
\hline 3 & $\begin{array}{l}\text { 1911, b } 1600(\mathrm{w}), 1576(\mathrm{~m}) \\
\text { 1549(m), 1383(s), 1170(m), } \\
\text { 1152(m), 1107(w), 1061(w), } \\
\text { 1029(w) }\end{array}$ & $\begin{array}{l}501(500), 390(3000), \\
310(22,000), 228(\mathrm{sh}, 25,000)\end{array}$ \\
\hline $3^{++}$ & $\begin{array}{l}\text { 1911, b 1972, } 1597(\mathrm{~m}) \\
\text { 1548(m), 1537(w), 1383(s), } \\
\text { 1152(m), 1107(m), 1090(w), } \\
\text { 1061(m), 1034(w), }\end{array}$ & $\begin{array}{l}917(625), 674(3500), \\
418(\mathrm{sh}, 10,000), 407(10,500), \\
306(15,000)\end{array}$ \\
\hline $3^{2+}$ & $\begin{array}{l}1973,^{\mathrm{b}} 1582(\mathrm{~m}), 1169(\mathrm{sh}) \\
1155(\mathrm{~m}), 1108(\mathrm{~m}), 1090(\mathrm{w}) \\
1062(\mathrm{~m}), 1036(\mathrm{w}), 1028(\mathrm{~m})\end{array}$ & $\begin{array}{l}676(1760), 421(\text { sh, } 6000) \\
405(6400), 300(16,600)\end{array}$ \\
\hline
\end{tabular}

ligands modeled as $\mathrm{PMe}_{3}$, geometry optimization leads to a broken symmetry solution (for details see Table S2 of the Supporting Information) and to the concentration of spin density on one styryl ruthenium subunit as it is depicted in Fig. 7 and listed in Table S3 of the Supporting Information. The CO stretching frequencies calculated at $1911 \mathrm{~cm}^{-1}$ for $2^{\text {Me }}$ are shifted to 1915 and $1950 \mathrm{~cm}^{-1}$ for monooxidized $2^{\mathrm{Me} \cdot+}$ and finally to 1963 and $1964 \mathrm{~cm}^{-1}$ for fully oxidized $2^{\text {Me } 2+}$ irrespective of the overall spin state (singlet diradical or triplet). It should be mentioned, though,

Table 4

The comparison of G09/PBE0/CPCM $\left(1,2-\mathrm{C}_{2} \mathrm{H}_{4} \mathrm{Cl}_{2}\right)$ calculated $\mathrm{CO}$ stretching frequencies for $\mathbf{1}^{\mathrm{Me} \mathbf{n}}, 2^{\mathrm{Me} \mathrm{n+}}$ and $3^{\mathrm{Me} \mathbf{n}}$ with experimental ones.

\begin{tabular}{|c|c|c|c|c|}
\hline & \multicolumn{2}{|c|}{ Calculated $^{\mathrm{a}}$} & \multicolumn{2}{|c|}{ Experimental } \\
\hline & $\nu_{1}(\mathrm{CO})$ & $\nu_{2}(\mathrm{CO})$ & $\nu_{1}(\mathrm{CO})$ & $\nu_{2}(\mathrm{CO})$ \\
\hline $1^{\text {Me }}$ & 1910 & - & 1910 & - \\
\hline $1^{\mathrm{Me} \cdot+}$ & 1957 & - & 1967 & - \\
\hline $2^{\mathrm{Me}}$ & 1911 & 1911 & 1909 & 1909 \\
\hline $2^{\mathrm{Me} \cdot+}$ & 1915 & 1950 & 1912 & 1963 \\
\hline \multirow[t]{2}{*}{$2^{\text {Me 2+ }}$} & $1962^{\mathrm{b}}$ & $1963^{b}$ & 1969 & 1969 \\
\hline & $1963^{c}$ & $1964^{c}$ & & \\
\hline $3^{\mathrm{Me}}$ & 1911 & 1912 & 1911 & 1911 \\
\hline $3^{\mathrm{Me} \cdot+}$ & 1915 & 1964 & 1912 & 1972 \\
\hline \multirow[t]{2}{*}{$3^{\text {Me 2+ }}$} & $1967^{b}$ & $1968^{\mathrm{b}}$ & 1972 & 1972 \\
\hline & $1967^{c}$ & $1968^{c}$ & & \\
\hline
\end{tabular}

${ }^{a}$ Calculated frequencies are scaled by a factor of 0.952 .

${ }^{b}$ Calculated for UKS singlet diradical state.

c Calculated for UKS triplet state. that the continuum model underlying the solvent correction is not wholly adequate considering that the X-ray structures of all vinyl ruthenium complexes that contain $\mathrm{CH}_{2} \mathrm{Cl}_{2}$ solvent molecules show specific hydrogen bonding between the ruthenium bonded chloride ligand and the $\mathrm{CH}_{2} \mathrm{Cl}_{2}$ solvent molecules.

EPR spectra were recorded on electrochemically oxidized samples of $\mathbf{1}^{+}, \mathbf{2}^{+}$and fully oxidized $\mathbf{2}^{\mathbf{2 +}}$ at various temperatures and concentrations in both the X-and the S-band (see Table 5 and Figures S2 and S3 of the Supporting Information). At $T=303 \mathrm{~K}$, monooxidized $\mathbf{1}^{\text {++ }}$ generated at a working potential of $0.6 \mathrm{~V}$ versus an $\mathrm{Ag}$ pseudo-reference electrode shows a three-line resonance signal at $g_{\text {iso }}=2.035$ with resolved ${ }^{31} \mathrm{P}$ hyperfine splitting of $22.5 \mathrm{G}$. Upon cooling, the spectra show anisotropy due to slow tumbling in solution which results in general signal broadening. No further couplings could be resolved even at lower modulation amplitudes. At $120 \mathrm{~K}$ in a rigidly frozen glass $\mathbf{1}^{++}$exhibits an axial $g$-matrix with individual $g$-values of $2.064\left(g_{\perp}\right)$ and $2.035\left(g_{11}\right)$ giving $\left.<\mathrm{g}_{\mathrm{av}}\right\rangle=2.045$. The proximity of $g_{\text {iso }}$ and $<\mathrm{g}_{\mathrm{av}}>$ to the $g$-value of the
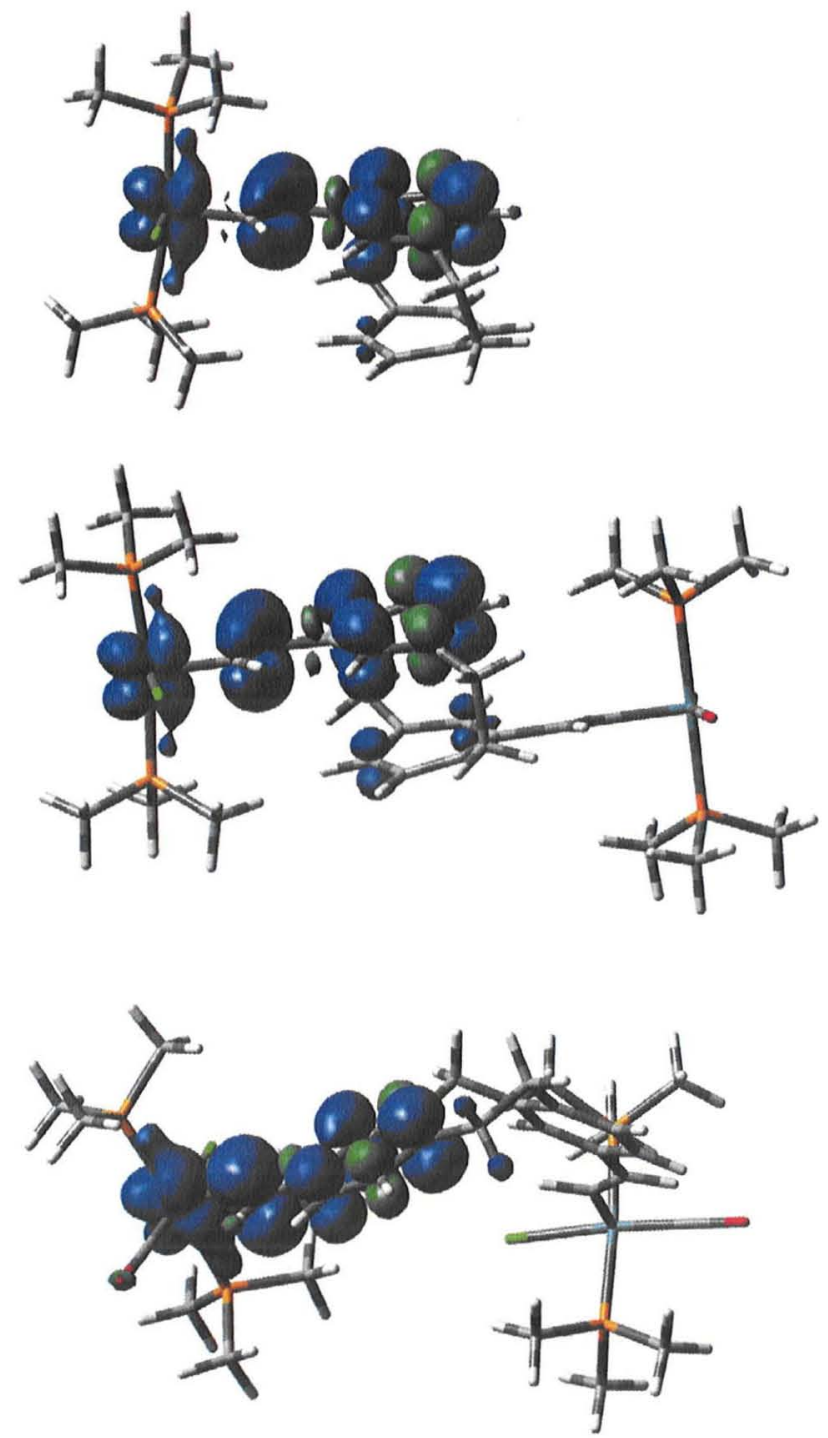

Fig. 7. DFT (PBE0/CPCM) calculated spin densities for $\mathbf{1}^{\mathrm{Me} \cdot+}$ (top), $\mathbf{2}^{\mathrm{Me} \cdot+}$ (middle), and $3^{\text {Me }}++$ (bottom). Blue and green colors indicate positive and negative spin density, respectively. (For interpretation of the references to colour in this figure legend, the reader is referred to the web version of this article. 
Table 5

EPR data for radical cations $1^{++}, 2^{++}, 3^{++}$and dioxidized $2^{2+}$ and $3^{2+}$

\begin{tabular}{|c|c|c|c|c|}
\hline \multirow[t]{2}{*}{ Complex } & \multicolumn{2}{|l|}{ Experimental } & \multicolumn{2}{|c|}{ Calculated } \\
\hline & $(T=273 \mathrm{~K})$ & $g_{\|}, g_{\perp}<g_{a v}>$ at $110 \mathrm{~K} ;(\Delta g)$ & $g_{\text {iso }}$ & $g_{1}, g_{2}, g_{3}\left(\Delta_{g}\right)$ \\
\hline $\mathbf{1}^{++}$ & $2.035 ; A\left({ }^{31} \mathrm{P}\right)=22.5 \mathrm{G}$ & $2.064,2.035<2.045>$; $(0.029)$ & 2.026 & $2.037,2.023,2.019(0.018)$ \\
\hline $2^{+}$ & 2.034 & $2.062,2.035<2.044>$; $(0.027)$ & 2.029 & $2.041,2.026,2.019(0.022)$ \\
\hline $2^{2+}$ & $2.034 ; A\left({ }^{31} \mathrm{P}\right)=22.7 \mathrm{G}$ & $2.061,2.035<2.044>;(0.026)$ & & \\
\hline $3^{+}$ & 2.040 & $2.071,2.036<2.048>$; $(0.035)$ & 2.037 & $2.052,2.035,2.024(0.028)$ \\
\hline $3^{2+}$ & $2.038 ; A\left({ }^{31} \mathrm{P}\right)=24.0 \mathrm{G}$ & $2.063,2.037<2.046>$; $(0.026)$ & & \\
\hline
\end{tabular}

free electron and the small $g$-matrix anisotropy $\Delta g$ of only 0.029 are both tokens of the dominant contribution of the arylvinyl ligand to the SOMO of the radical cation as has been observed on previous occasions [74,81,85,90-92]. Monooxidized $\mathbf{2}^{++}$gives an isotropic signal at $g=2.034$. A broadening of the signal and some inflections suggest underlying hyperfine splittings which, however, were not resolved at any temperature in the $303-203 \mathrm{~K}$ range. Again we observe anisotropic signal broadening as the temperature is lowered. At $120 \mathrm{~K}$, the signal is axial with $g$-values of $2.062\left(g_{\perp}\right)$ and $\left.2.035\left(g_{11}\right)\left(<g_{a v}\right\rangle=2.044\right)$. When the electrolysis was performed for a longer time at an applied potential of $1.0 \mathrm{~V}\left(\mathrm{vs} . \mathrm{Ag} / \mathrm{Ag}^{+}\right)$, i.e. at a potential sufficiently anodic of the $\mathbf{2}^{+/ 2+}$ wave, a strong isotropic signal with well-resolved ${ }^{31} \mathrm{P}$ hyperfine splitting of $22.7 \mathrm{G}$ was observed at $g_{\text {iso }}=2.034$ that we assign to dioxidized $2^{2+}$. Cooling of the solution caused signal broadening with the partial loss of resolution until, in the frozen glass, an axial signal with $g_{\perp}=2.061$, $\mathrm{g}_{11}=2.035$ and $\left\langle\mathrm{g}_{\mathrm{av}}\right\rangle=2.044$ was obtained. No half-field signal was detected in either the fluid or the frozen solutions. Solutions of $\mathbf{2}^{++}$generated by extensive electrolysis of $\mathbf{2}$ at an applied potential of $0.6 \mathrm{~V}$ (against $\mathrm{Ag} / \mathrm{Ag}^{+}$) did not show any better resolution in the $\mathrm{S}$-band than those recorded in the X-band (see Figure S5 of the Supporting Information). Individual $g$-values and anisotropies for $2^{\mathrm{Me} \cdot+}$ were also calculated by DFT (see Table 5 ) and are in good agreement with experimentally measured ones. UKS calculations on doubly oxidized $2^{\text {Me } 2+}$ were performed on diradical singlet and triplet states. Both states are energetically close, the singlet being slightly more stable by about $0.01 \mathrm{eV}$. In both states the spin density is almost equally spread over the both vinyl ruthenium subunits (Figure S7).

\subsection{Half-open, ortho-connected 3: an analog of $\mathbf{2}$ without $\pi$ - stacking}

There is a general consensus that through-space (i.e. $\pi$-stacking) and through-bond pathways are both relevant for electron delocalization in odd-electron [n.n]paracyclophanes [22,42]. Literature data are, however, somewhat inconclusive with respect to the relative contributions of the two complementary pathways to overall charge and spin delocalization. In an attempt to shed more light on this issue we prepared the dinuclear complex $\mathbf{3}$ as a halfopen "[2.1]orthocyclophane" analog of $\mathbf{2}$ where the two styryl decks are non-parallel and kept apart (Chart 1; for the DFToptimized structure see Figure S6 of the Supporting Information). In order to render both available through-bond pathways roughly equivalent and comparable to those in $\mathbf{2}$, the longer ethylene linker is placed in direct conjugation with the styryl ruthenium subunits (i.e. the para position) while the shorter methylene strap is in the less favorable meta one.

Complex 3 was prepared from 3,7-diethynyl-10,11-dihydro-5Hdibenzo[a,d]cycloheptene and the hydride complex $\mathrm{RuClH}(\mathrm{CO})(-$ $\left.\mathrm{P}^{i} \mathrm{Pr}_{3}\right)_{2}$. It is authenticated by the characteristic ${ }^{1} \mathrm{H}$ and ${ }^{13} \mathrm{C}$ NMR resonances of the vinyl ruthenium subunit at $8.43(\mathrm{Ru}-\mathrm{CH}=\mathrm{CH})$, $5.90(\mathrm{RuCH}=\mathrm{CH}), 149.0(\mathrm{Ru}-\mathrm{CH})$ and $134.4(\mathrm{Ru}-\mathrm{CH}=\mathrm{CH}) \mathrm{ppm}$ and the expected signals of the bridging methylene groups at $3.91\left(\mathrm{CH}_{2}\right)$ and $3.02\left(\mathrm{C}_{2} \mathrm{H}_{4}\right) \mathrm{ppm}$ as well as by one singlet signal at $38.4 \mathrm{ppm}$ in ${ }^{31} \mathrm{P}$ NMR spectroscopy. IR features include the characteristic Ru(CO) stretch at $1911 \mathrm{~cm}^{-1}$ and $C=C$ bands at 1576 and $1549 \mathrm{~cm}^{-1}$. Voltammetric measurements show two chemically reversible oneelectron processes that are merged into a composite wave in cyclic voltammetry but are resolved into individual peaks in differential pulse and square wave voltammetric experiments (Fig. 8, Table 2). Digital simulation of representative cyclic voltammograms [93] or deconvolution of the square wave voltammograms yield a half-wave potential difference $\Delta E_{1 / 2}$ of $105( \pm 3)$ $\mathrm{mV}$ and, according to Eq. (1), a comproportionation constant $K_{\text {comp }}$ of $64( \pm 8)$. This is to be compared with a value of $4.1( \pm 9) \times 10^{3}$ for 2 $\left(\Delta E_{1 / 2}=210( \pm 5)\right) \mathrm{mV}$ where $\pi$-stacking is operative

$K_{\text {comp }}=\exp \left\{\left(n \cdot F \cdot \Delta E_{1 / 2}\right) /(R \cdot T)\right\}$

Spectroelectrochemical measurements were undertaken in order to determine the electronic coupling in monooxidized $3^{*+}$. IR spectroelectrochemistry again revealed the presence of two consecutive one-electron steps with the appearance of two $\mathrm{Ru}(\mathrm{CO})$ bands during the first and their merging into a single one upon the second oxidation (Fig. 9). This information is, however, hard to glean from the experimental mid IR spectra pattern alone since there is apparently no shift from the band of $\mathbf{3}$ to the low-energy feature of $3^{+}$and from the high-energy band of $3^{++}$to the single one in dioxidized $\mathbf{3}^{\mathbf{2}}$. There is, however, a broad high-energy feature whose maximum lies just outside our detector range that first grows in and then collapses as the oxidation from 3 to $3^{\cdot+}$ and

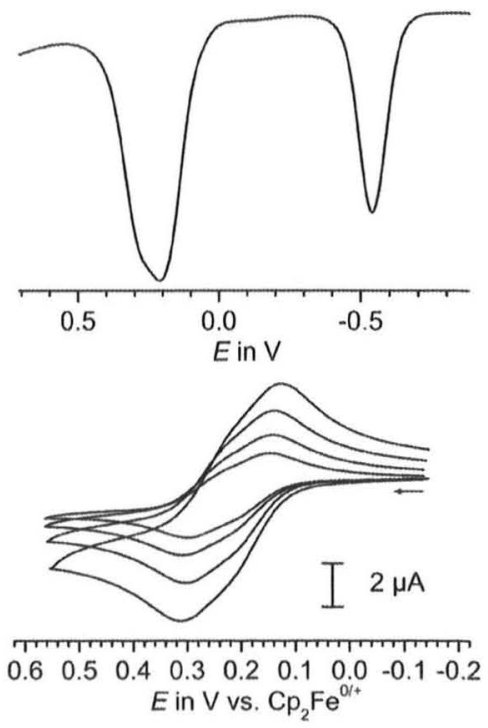

Fig. 8. Electrochemical investigations on complex 3 in $\mathrm{CH}_{2} \mathrm{Cl}_{2} / \mathrm{NBu}_{4} \mathrm{PF}_{6}(0.1 \mathrm{M})$ at $\mathrm{r}$. $\mathrm{t}$ Bottom: Cyclic voltammetry at sweep rates of $50,100,200$, and $500 \mathrm{mV} / \mathrm{s}$; top: Square Wave Voltammetry; the peak on the right hand side corresponds to the internal $\mathrm{Cp}_{2}^{*} \mathrm{Fe}^{\mathrm{O} /+}$ couple. 

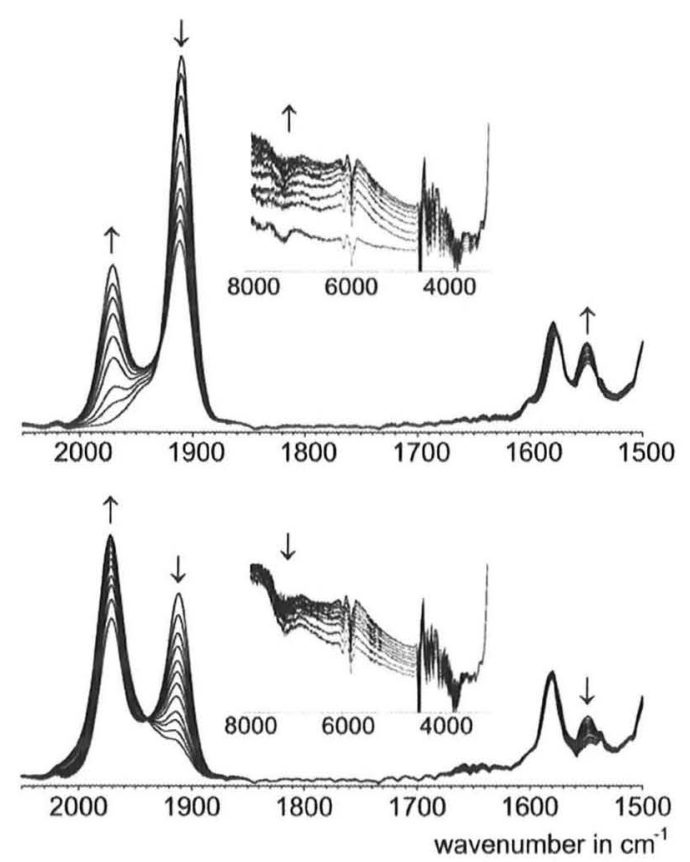

Fig. 9. Changes in the IR spectra upon the first (top) and second (bottom) oxidation of complex $3\left(1,2-\mathrm{C}_{2} \mathrm{H}_{4} \mathrm{Cl}_{2} / \mathrm{NBu}_{4} \mathrm{PF}_{6}(0.2 \mathrm{M})\right.$ at $\mathrm{t}$ ). Insert: Range from 3000 to $8000 \mathrm{~cm}^{-1}$ showing the IVCT transition of the intermediate radical cation $3^{+}$.

then to $3^{2+}$ proceeds (see insert of Fig. 9). The spectrum with the highest absorbance of this band thus defines the point at which the concentration of monooxidized $3^{+}$reaches its maximum. This low-energy band extending into the IR region is also seen in UV/ Vis/NIR spectroelectrochemical experiments (see insert of Fig. 10). It has no equivalent in oxidized $\mathbf{1}^{+}$but resembles that observed in $\mathbf{2}^{+}$. It is thus therefore assigned as the IVCT transition of $\mathbf{3}^{++}$. Band parameters as determined by spectral deconvolution are $\tilde{\nu}_{\max }=10,900 \mathrm{~cm}^{-1} \quad(917 \mathrm{~nm}), \quad \varepsilon_{\max }=625 \mathrm{I} \mathrm{mol}^{-1} \mathrm{~cm}^{-1} \quad$ and $\Delta \tilde{\nu}_{1 / 2}=4250 \mathrm{~cm}^{-1}$. The typical bands of the oxidized styryl ruthenium chromophore are also observed as structured bands near $675 \mathrm{~nm}$ and $410 \mathrm{~nm}$ (Fig. 10); deconvoluted peak positions and extinction coefficients are given in Table 3.

EPR studies on electrogenerated $\mathbf{3}^{++}$(electrolysis at $0.6 \mathrm{~V}$ ) and fully oxidized $3^{2+}$ (prolonged electrolysis at $1.0 \mathrm{~V}$ ) resulted in the

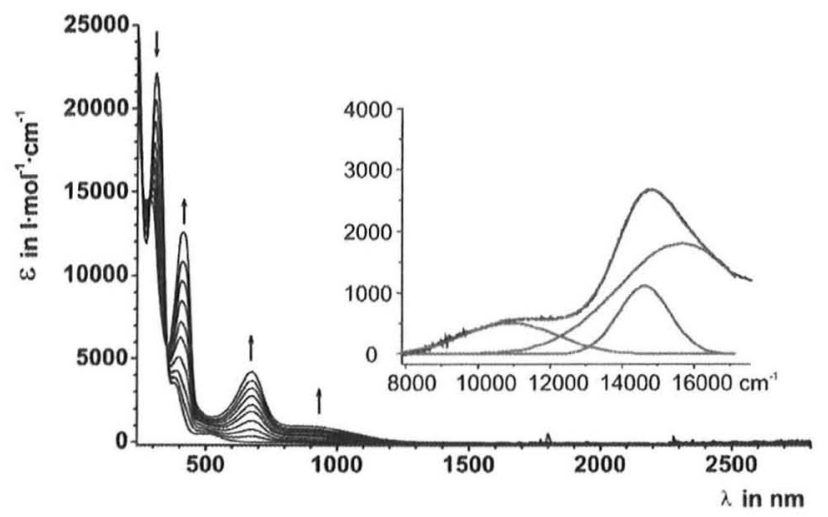

Fig. 10. Changes in the UV/Vis/NIR spectra upon the first oxidation of complex $3(1,2$ $\mathrm{C}_{2} \mathrm{H}_{4} \mathrm{Cl}_{2} / \mathrm{NBu}_{4} \mathrm{PF}_{6}(0.2 \mathrm{M})$ at $\mathrm{r}$. $\mathrm{t}$.). Insert: Deconvolution of the bands at low-energy. Experimental spectrum (black line), deconvoluted individual bands (green lines), and superposition of individual bands (red line). (For interpretation of the references to colour in this figure legend, the reader is referred to the web version of this article.) same observations as in the case of the corresponding paracyclophanes $\mathbf{2}^{++}$and $\mathbf{2}^{2+}$. Thus, $\mathbf{3}^{++}$gave a broadened isotropic signal at $\mathrm{g}=2.040$ without resolved ${ }^{31} \mathrm{P}$ hyperfine splittings which further broadened upon cooling and finally turned into an axial pattern at $T=120 \mathrm{~K}$ in the frozen matrix. As for $2^{+}$, the spectral resolution and band widths of electrogenerated samples of $3^{++}$did not change when they were recorded in the S-band. Prolonged electrolysis at $1.0 \mathrm{~V}$, a potential sufficiently positive of the $3^{+/ 2+}$ couple, produced a binomial 1:2:1 three-line signal at r.t. at $\mathrm{g}=2.038$ with $A\left({ }^{31} \mathrm{P}\right)=24.0 \mathrm{G}$. Freezing the solution to $120 \mathrm{~K}$ changed the spectrum to an axial pattern $\left(g_{\perp}=2.063, g_{11}=2.037\right.$, $\left.<g_{\text {av }}\right\rangle=2.046$ ), again with no half-field signal detected (Table 5 and Figure S4 of the Supporting Information). The somewhat larger $g$-values and $A\left({ }^{31} \mathrm{P}\right)$ coupling constants of $3^{\text {n+ }}$ when compared to those of $2^{\mathrm{n}+}$ argue for an increased metal contribution of the SOMO and are well reproduced by our quantum chemical calculations (see Table 5 and Table S3 of the Supporting Information).

\section{Discussion}

The main issue of this study was to experimentally probe for the strength of the electronic coupling in the mixed-valent radical cations $\mathbf{2}^{+}$and $\mathbf{3}^{++}$and for the extent to which the $\pi$-stacking (or through-space) pathway and the through-bond pathway via the saturated alkylene straps contribute to it. While information as to the extent of electron delocalization in mixed-valent systems can in principle be obtained from several spectroscopic or even computational methods, the oxidation-induced IR band shifts provide the most straightforward access to electron delocalization in the radical cations $\mathbf{2}^{+}$and $\mathbf{3}^{+}$. Geiger et al. have defined a charge distribution parameter $\Delta \rho$ according to Eq. (2) which is based on the relative shifts of the charge-sensitive CO stretches of metal-bonded carbonyl ligands with respect to the bordering isovalent ones $[22,94]$. In Eq. (2), $\nu_{\text {ox }}$ and $\nu_{\text {red }}$ denote the band positions of the IR label in the fully oxidized and the fully reduced forms while $\nu_{0 x}^{\prime}$ and $\nu^{\prime}$ red are the band positions of the (formally) oxidized and (formally) reduced subunit of a mixed-valent system. According to that definition, $\Delta \rho$ may assume values ranging from 0 to 0.5 where a value of 0 denotes the class I limit of a mixed-valent system with fully localized valencies on two non-interacting redox sites while $\Delta \rho=0.5$ heralds the class III limit of full charge delocalization $[22,94]$.

$$
\Delta \rho=\left[\left(v_{\mathrm{ox}}-v_{\mathrm{ox}}^{\prime}\right)+\left(v_{\text {red }}^{\prime}-v_{\text {red }}\right)\right] / 2\left(v_{\mathrm{ox}}-v_{\text {red }}\right)
$$

Experimental data on the $\mathbf{2}^{\mathbf{0 / +}+\mathbf{2}+}$ redox series (Table 3) yield a $\Delta \rho$ value of 0.08 for $2^{++}$. According to that result $2^{++}$is a moderately coupled class II mixed-valent system. In keeping with that assignment $\mathbf{2}^{++}$displays a characteristic low-energy electronic absorption band at $\lambda=1828 \mathrm{~nm}\left(\tilde{\nu}_{\max }=5470 \mathrm{~cm}^{-1}\right)$ with $\varepsilon_{\max }=1100 \mathrm{lmol}^{-1} \mathrm{~cm}^{-1}$ and $\Delta \tilde{\nu}_{1 / 2}=4870 \mathrm{~cm}^{-1}$. This band has no equivalent in oxidized $\mathbf{1}^{++}$(whose UV/Vis/NIR spectrum otherwise closely resembles that of $\mathbf{2}^{++}$) with only one styryl ruthenium moiety, or in reduced 2 and fully oxidized $\mathbf{2}^{2+}$, where the two styryl ruthenium subunits are isovalent.

The combined effects of a very small magnitude of the oxidation-induced $\mathrm{Ru}(\mathrm{CO})$ band shifts and of the only moderate comproportionation constant $K_{\mathrm{c}}$ pose a particular problem when determining the $\mathrm{CO}$ band positions (and hence $\Delta \rho$ ) of $3^{\cdot+}$. A $K_{\mathrm{c}}$ value of 64 dictates that, at the point of maximum concentration of the intermediate radical cation, $80 \%$ of the total amount of compound 3 are in the $3^{+}$oxidation state whereas $10 \%$ of reduced 3 and fully oxidized $3^{2+}$ each are present. Based on this consideration, the hypothetical spectrum of $3^{++}$can be calculated from the 
experimental curves. Estimated $\nu(\mathrm{CO})$ values are 1911 and $1972 \mathrm{~cm}^{-1}$ as compared to $1911 \mathrm{~cm}^{-1}$ for 3 and $1973 \mathrm{~cm}^{-1}$ for $3^{2+}$. From that result it is clear that the charge distribution parameter for $\mathbf{3}^{\cdot+}$ is, at best, rather small and no larger than 0.01. Nevertheless, $3^{+}$also features an electronic band at fairly low-energy $\left(\tilde{\nu}_{\max }=10,900 \mathrm{~cm}^{-1}, \lambda_{\max }=917 \mathrm{~nm}\right)$ besides additional absorptions that are characteristic of the oxidized styryl ruthenium chromophore. This band has no equivalent in $\mathbf{1}^{++}, \mathbf{3}$ and $\mathbf{3}^{\mathbf{2 +}}$ and is thus also likely of IVCT origin. Taken together, $\mathbf{3}^{++}$may be classified as a weakly to very weakly coupled mixed-valent system of class II.

These conclusions based on experimental evidence are supported by our quantum chemical calculations on the $\mathrm{PMe}_{3}$ ligated model complexes $2^{\mathrm{Me} \cdot+}$ and $3^{\mathrm{Me} \cdot+}$. The calculated energy difference between the two $\mathrm{CO}$ stretches is considerably smaller for $3^{\mathrm{Me}++}$ as for $2^{\mathrm{Me}+}$. Calculated structures and spin density distributions upon oxidation also point to a different degree of groundstate charge and spin delocalization for the radical cations. For $3^{\mathrm{Me} \cdot+}$, removal of an electron structurally affects just one styryl ruthenium site while there are hardly any changes on the other. In contrast, both styryl ruthenium sites are affected upon oxidation of $2^{\mathrm{Me}}$ to $2^{\mathrm{Me} \cdot+}$, albeit to a different degree. Moreover, the DFT (PBEO/ CPCM) calculated spin density distribution shows that the unpaired spin resides on just one $\{\mathrm{Ru}\}$-styryl subunit of the half-open orthocyclophane $3^{\mathrm{Me} \bullet+}$ whereas there is some degree of spin delocalization between the two styryl ruthenium decks in the true [2.2] paracyclophane radical cation $2^{\text {Me.+ }}$, (see Fig. 7 and Tables S2 and S3 of the Supporting Information).

The above conclusions pertain to the intrinsic electronic groundstate delocalization on the timescale of molecular vibrations, that is on timescales shorter than $10^{-11} \mathrm{~s}$. They, however, provide not much information about electron transfer dynamics. EPR is a highly useful tool to address this issue since it operates on a slower timescale of ca. $10^{-8} \mathrm{~s}$. EPR investigations on the radical anions of [2.2]paracyclophanes [41] or their dinitro derivatives [43] or on the radical cations derived from electron-rich anisyl-derived or triarylamine-decorated $[2,2]$ and $[3,3]$ paracyclophanes identified them as intrinsically delocalized systems on the EPR timescale with electron transfer rates of ca. $1 \cdot 10^{8} \mathrm{~s}^{-1}$, irrespective of the strap lengths [45-47]. Our failure to observe resolved hyperfine splittings in the X-band and S-band EPR spectra of radical cations $2^{+}$ and $3^{+}$unfortunately does not allow us to determine the rates of intramolecular electron transfer for these systems. Insufficient signal resolution for detailed analysis might originate from a larger number of unresolved hyperfine interactions with smaller coupling constants when compared to $\mathbf{1}^{\cdot+}$ with just one oxidized styryl ruthenium entity. A doubling of the number of hyperfine splittings with simultaneous reduction of coupling constants by one half is expected of a mixed-valent system with the spin delocalized over two redox-active subunits and has been documented on several occasions. Instructive examples are Kochi's triphenylenes where two redox-active 4-methyl-2,5-dimethoxyphenyl entities are bridged by a central para-phenylene or -diphenylene bridge [95], Gladysz's butadiynediyl-bridged dirhenium complex $[\{\mathrm{Cp} * \mathrm{Re}(-$ $\left.\left.\mathrm{NO})\left(\mathrm{PPh}_{3}\right)\right\}_{2}\left(\mu-\mathrm{C}_{4}\right)\right]^{+}$and its $\mathrm{Pd} / \mathrm{Re}_{2}$ counterpart trans-[\{Cp* $\mathrm{Re}(-$ $\left.\left.\mathrm{NO})\left(\mathrm{PPh}_{3}\right)\left(\mu-\mathrm{C}_{4}\right)\right\}_{2} \mathrm{Pd}\left(\mathrm{PPh}_{3}\right)_{2}\right]^{++}\left(\mathrm{Cp}^{*}=\eta^{5}-\mathrm{C}_{5} \mathrm{Me}_{5}\right)$ [96] and the bis(triarylamine)-appended paracyclophanes of Lambert and Grampp (see Chart 2 for these systems) [47]. Another possible source of signal broadening is homogeneous electron self-exchange between the radical cations and the remaining neutrals in case of incomplete oxidation of the neutral precursors to their radical cations. Our present inability to produce pure samples $\mathbf{2}^{++}$and $\mathbf{3}^{++}$ by means of chemical oxidation $\left(\mathrm{Ag}^{+}\right.$or acetylferrocenium) or by quantitative coulometry under appropriate conditions does not allow us to discriminate between these two possibilities. We nevertheless note that similar [2.2]paracyclophane-bridged mixedvalent radicals are all delocalized on the EPR timescale (see above) and that the radical cation spectra of the triarylamine-substituted paracyclophanes of Grampp's and Lambert's study were all obtained in the presence of a ninefold excess of the corresponding neutral [47]. We therefore consider the first explanation as the more likely one. This view is also supported by our observation that the X-and S-band EPR spectra of $\mathbf{2}^{+}$and $\mathbf{3}^{++}$are basically identical: If the broadening was due to exchange the relative rates of that exchange and of the experiment would be altered and a narrowing of the spectra would be expected.

Secondly, the absence of a half-field signal for dioxidized $\mathbf{2}^{2+}$ and $3^{2+}$ indicates, that the unpaired spins behave independently as insulated spins, i.e, electronic coupling in the dioxidized state is, at best, very weak. Our calculations on $2^{\text {Me } 2+}$ and $3^{\text {Me } 2+}$ indeed place diradical singlet and triplet ground states very close in energy with

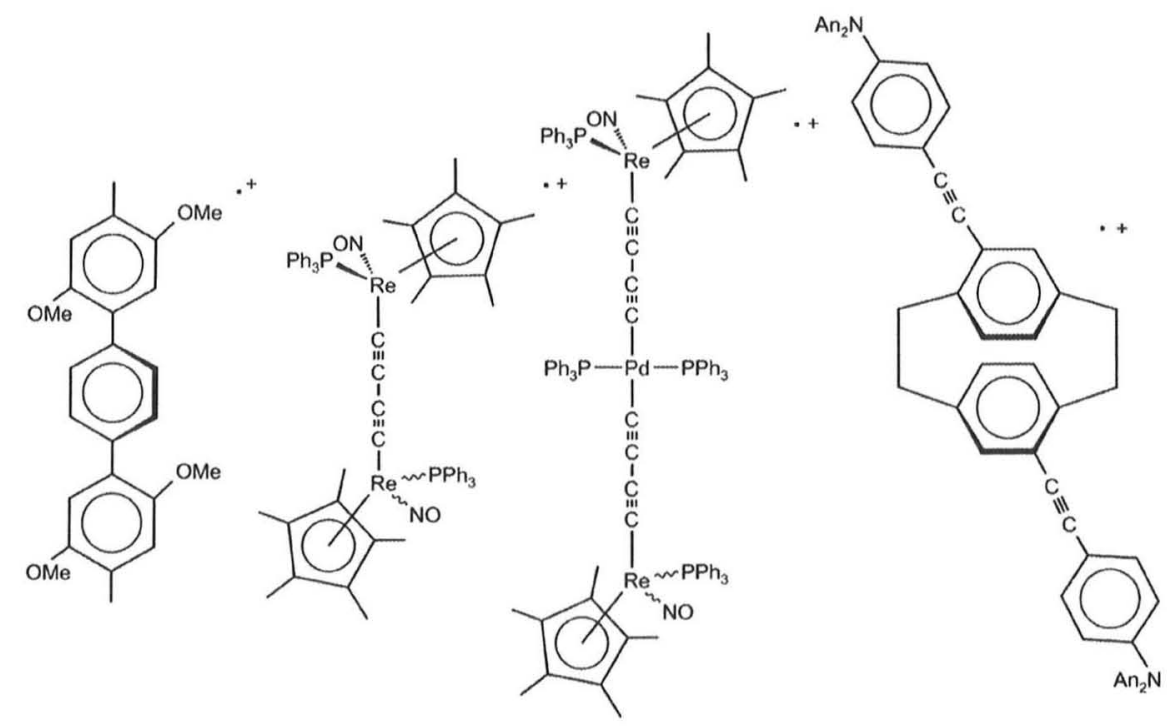

Chart 2. An = anisyl, 4- $\mathrm{MeOC}_{6} \mathrm{H}_{4}$. 
the singlet diradical state as the slightly preferred one. For each form the spin density is almost equally spread over both vinyl ruthenium subunits.

\section{Conclusions}

Complexes 2 and 3 feature two interlinked styryl-Ru(CO) $\mathrm{Cl}\left(\mathrm{PiPr}_{3}\right)_{2}$ subunits, whose phenyl rings are integrated into a [2.2] paracyclophane or a [2.1]orthocyclophane system. These two architectures have virtually identical through-bond distances between the individual styryl ruthenium chromophores and their metal centers but strongly differ with respect to the mutual arrangements of the arene decks. Enforced $\pi$-stacking at distances well beyond the sum of the van der Waals radii in the case of the [2.2] paracyclophane-derived complex $\mathbf{2}$ contrasts with a considerably larger separation and a strong tilt induced by the ortho ethylene and methylene hinges in $\mathbf{3}$. Complexes $\mathbf{2}$ and $\mathbf{3}$ are thus ideal probes for studying the mutual contributions of the "through-space" and "through-bond" pathways for electron delocalization in such odd-electron phane architectures. The relative shifts of the $\mathrm{Ru}(\mathrm{CO})$ bands upon stepwise oxidation to their radical cations $2^{++}$and $3^{++}$and their dications $2^{2+}$ and $3^{2+}$ provide a quantitative measure of ground-state delocalization through the charge distribution parameter $\Delta \rho$. Based on the experimental $\Delta \rho$ values, $2^{++}$is a moderately and $3^{++}$a weakly coupled mixed-valent system of class II. The direct comparison of $2^{++}$and $3^{+}$, which only differ with respect to the mutual arrangement of the individual styryl ruthenium subunits, suggests that the through-space pathway dominates over the through-bond one in effecting delocalization in mixed-valent, odd-electron [2.2]paracyclophanes. This is under the assumption that delocalization via the through-bond pathway is equal for both compounds. Our results on odd-electron radical cations $2^{++}$and $3^{\cdot+}$ contrast to quantum chemical calculations on neutral closed-shell paracyclophanes, where the through-bond pathway was calculated to be the more efficient one for the [2.2]paracyclophane architecture [97].

Quantum chemical calculations on the simplified mode complexes $2^{\mathrm{Me} \mathrm{n+}}$ and $3^{\mathrm{Me} \mathrm{n+}}$ with the $\mathrm{P}^{i} \mathrm{Pr}_{3}$ ligands replaced by $\mathrm{PMe}_{3}$ reproduce the experimental structure of $\mathbf{2}$ and predict that radical cation $2^{\mathrm{Me}++}$ assumes a completely delocalized electronic structure in the gas phase. Inclusion of the CPCM solvent correction, however, reproduced our experimental findings of partial or weak ground-state delocalization in $2^{+}$and $3^{++}$as is indicated by the structural differences between the individual styryl halves, the good agreement of the calculated $\mathrm{CO}$ band splittings with the experimental ones and by the calculated spin density distributions.

Radical cations $2^{\cdot+}$ and $3^{\cdot+}$ show a moderately intense electronic NIR band which, by comparison with the spectra of the reduced or dioxidized forms and those of the monoruthenium [2.2] paracyclophane radical cation $\mathbf{1}^{+}$, is identified as an intervalence charge-transfer (IVCT) transition.

\section{Acknowledgment}

We are grateful to Deutsche Forschungsgemeinschaft (project Wi 1272/7-2) for financial support of this work. S. Z. wishes to thank the Ministry of Education of the Czech Republic (Grant COST LD11086) and the Grant Agency of the Academy of Sciences of the Czech Republic (KAN100400702). We also wish to thank Silvia Domingo-Köhler and Dr. Malte Drescher for the recording of additional EPR spectra of complex $\mathbf{1}^{+}$. R. F. W. also wishes to thank a referee for insightful comments and Prof. Dr. Stephan Landgraf (Technical University of Graz) for helpful discussions.

\section{Appendix. Supporting Information}

Supplementary data associated with this article can be found in the online version, at doi:10.1016/j.jorganchem.2011.06.028.

\section{References}

[1] J.W. Steed, J.L. Atwood, Supramolecular Chemistry, Wiley, Chichester, 2000

[2] Z. Chen, A. Lohr, C.R. Saha-Moeller, F. Würthner, Chem. Soc. Rev. 38 (2009) 564-584.

[3] H. Roesky, M. Andruh, Coord. Chem. Rev. 236 (2003) 91-119.

[4] C. Janiak, J. Chem. Soc., Dalton Trans. (2000) 3885-3896.

[5] P. Douglas, F.J. Stoddart, Angew. Chem. Int. Ed. Engl. 35 (1996) 1155-1196.

[6] N.W. Alcock, P.R. Barker, J.M. Haider, M.J. Hannon, C.L. Painting, Z. Pikramenou, E.A. Plummer, K. Rissanen, P. Saarenketo, Dalton Trans. (2000) 1447-1462.

[7] A.S. Ionkin, W.J. Marshall, Y. Wang, Organometallics 24 (2005) 619-627.

[8] J.W. Hong, H.Y. Woo, B. Liu, G.C. Bazan, J. Am. Chem. Soc. 127 (2005) $7435-7443$.

[9] S.R. Amrutha, M. Jayakannan, J. Phys. Chem. B 110 (2006) 4083-4091.

[10] P. Shen, G. Sang, J. Lu, B. Zhao, M. Wan, Y. Zou, Y. Li, S. Tan, Macromolecules 41 (2008) 5716-5722.

[11] Y. Yamauchi, M. Yoshizawa, M. Fujita, J. Am. Chem. Soc. 130 (2008) $5832-5833$.

[12] L.-L. Li, K.-J. Lin, C.-J. Ho, C.-P. Sun, H.-D. Yang, Chem. Commun. (2006) 1286-1288.

[13] C. Elschenbroich, M. Wolf, O. Schiemann, K. Harms, O. Burghaus, J. Pebler, Organometallics 21 (2002) 5810-5819.

[14] T. Cauchy, E. Ruiz, O. Jeannin, M. Nomura, M. Formigué, Chem. Eur. J. 13 (2007) 8858-8866.

[15] C. Elschenbroich, B. Kanellakopulos, F.H. Köhler, B. Metz, R. Lescouëzec, N. Mitzel, W. Strauß, Chem. Eur. J. 13 (2007) 1191-1200.

[16] K.M. Knoblock, C.J. Silvestri, D.M. Collard, J. Am. Chem. Soc. 128 (2006) $13680-13681$

[17] C. Hou, J.-M. Shi, Y.-M. Sun, W. Shi, P. Cheng, L.-D. Liu, Dalton Trans. (2008) 5970-5976.

[18] D.L. Reger, A. Debreczeni, B. Reinecke, V. Rassolov, M.D. Smith, Inorg. Chem. 58 (2009) 8911-8924.

[19] I.V. Fedyanin, K.A. Lyssenko, Z.A. Starikova, M.Y. Antipin, Russ. Chem. Bulletin 53 (2004) 1153-1158.

[20] P.J. Ball, T.R. Shtoyko, J.A. Krause Brauer, W.J. Oldham, W.B. Connick, Inorg. Chem. 43 (2004) 622-632.

[21] J. Casado, K. Takimiya, T. Otsubo, F.J. Ramírez, J.J. Quirante, R.P. Ortiz, S.R. González, J.T. López Navarrete, J. Am. Chem. Soc. 130 (2008) $14028-14029$.

[22] M.E. Stoll, S.R. Lovelace, W.E. Geiger, H. Schimanke, I. Hyla-Kryspin, R. Gleiter, J. Am. Chem. Soc. 121 (1999) 9343-9351.

[23] S. Gath, R. Gleiter, F. Rominger, C. Bleiholder, Organometallics 26 (2007) 644-650.

[24] S.F. Nelsen, G. Li, K.P. Schultz, H.Q. Tran, I.A. Guzei, J. Am. Chem. Soc. 130 (2008) 11620-11622

[25] D.-L. Sun, S.V. Rosokha, S.V. Lindeman, J.K. Kochi, J. Am. Chem. Soc. 125 (2003) 15950-15963.

[26] A. Fürstner, M. Alcarazo, H. Krause, C.W. Lehmann, J. Am. Chem. Soc. 129 (2007) $12676-12677$

[27] G.B. Bartholomew, G.C. Bazan, Acc. Chem. Res. 34 (2001) 30-39.

[28] Y. Tanaka, T. Ozawa, A. Inagaki, M. Akita, Dalton Trans. (2007) 928-933.

[29] M.R. Arkin, E.D.A. Stemp, R.E. Holmlin, J.K. Barton, A. Hörmann, E.J.C. Olson, P.F. Barbara, Science 273 (1996) 475-480.

[30] S.O. Kelly, K.K. Barton, Chem. Biol. 5 (1998) 413-425.

[31] T.T. Tashica, J.K. Barton, in: M. Demeunynck, C. Bailly, W.D. Wilson (Eds.), Small Molecule DNA and RNA Binders, Wiley-VCH, Weinheim, Germany, 2003, pp. 146-177.

[32] A. Tirosi, Mol. Simulat. 32 (2006) 707-716.

[33] A. van de Craats, N. Stutzmann, O. Bunk, M.N. Nielsen, M. Watson, K. Müllen, H.D. Chanzy, H. Sirringhaus, R.H. Friend, Adv. Mater. 15 (2003) 495-499.

[34] L. Li, S.-W. Kang, J. Harden, Q. Sun, X. Zhu, L. Dai, A. Jakli, S. Kumar, Q. Li, Liquid Crystals 35 (2008) 233-239.

[35] S. Laschat, A. Baro, N. Steinke, F. Giesselmann, C. Hägele, G. Scalia, R. Judele E. Kapatsina, S. Sauer, A. Schreivogel, M. Tosoni, Angew. Chem. Int. Ed. Engl. 46 (2007) 4832-4887.

[36] S. Sergeyev, W. Pisula, Y.H. Geerts, Chem. Soc. Rev. 36 (2007) 1902-1929.

[37] S. Rathgeber, D. Bastos de Toledo, E. Birckner, H. Hoppe, D.A.M. Egbe, Macromolecules 43 (2010) 306-315.

[38] P.H. Dinolfo, M.E. Williams, C.L. Stern, J.T. Hupp. J. Am. Chem. Soc. 126 (2004) 12989-13001.

[39] P.H. Dinolfo, J.T. Hupp, J. Am. Chem. Soc. 126 (2004) 16814-16819.

[40] P.H. Dinolfo, S.J. Lee, V. Coropceanu, J.-L. Brédas, J.T. Hupp, Inorg. Chem. 44 (2005) 5789-5797.

[41] F. Gerson, Top. Curr. Chem. 115 (1983) 57-105.

[42] S. Amthor, C. Lambert, J. Phys. Chem. A 110 (2006) 1177-1189.

[43] S.F. Nelsen, A.E. Konradsson, J.P. Telo, J. Am. Chem. Soc. 127 (2005) 920-925.

[44] Y. Morisaki, Y. Chujo, Angew. Chem. Int. Ed. Engl. 45 (2006) 6430-6437. 
[45] A. Wartini, J. Valenzuela, H.A. Staab, F.A. Neugebauer, Eur. J. Org. Chem. (1998) $139-148$.

[46] A. Wartini, H.A. Staab, F.A. Neugebauer, Eur. J. Org. Chem. (1998) 1161-1170

[47] D.R. Kattnig, B. Mladenova, G. Grampp, C. Kaiser, A. Heckmann, C. Lambert, J. Phys. Chem. C 113 (2009) 2983-2995.

[48] M. Krejcik, M. Danek, F. Hartl, J. Electroanal. Chem. 317 (1991) 179-187.

[49] P.R. Murray, L.J. Yellowlees, in: W. Kaim, A. Klein (Eds.), Spectroelectrochemistry, RSC Publishing, Cambridge, 2008, pp. 207-231.

[50] M.A. Esteruelas, H. Werner, J. Organomet. Chem. 303 (1986) 221-231.

[51] S. Clément, L. Guyard, M. Knorr, S. Dilsky, C. Strohmann, M. Arroyo, J. Organomet. Chem. 692 (2007) 839-850.

[52] M. Holzapfel, C. Lambert, J. Phys. Chem. C 112 (2008) 1227-1243.

[53] M.J. Frisch, G. Trucks, H.B. Schlegel, G.E. Scuseria, M.A. Robb, J.R. Cheeseman, G. Scalmani, V. Barone, B. Mennucci, G.A. Petersson, H. Nakatsuji, M. Caricato, X. Li, H.P. Hratchian, A.F. Izmaylov, J. Blonio, G. Zheng, J.L. Sonnenberg, M. Hada, M. Ehara, K. Toyota, R. Fukuda, J. Hasegawa, M. Ishida, T. Nakajima, Y. Honda, O. Kitao, H. Nakai, T. Vreven, J.A. Montgomery Jr., J.E. Peralta, F. Ogliaro, M. Bearpark, J.J. Heyd, E. Brothers, K.N. Kudin, V.N. Staroverov, R. Kobayashi, J. Normand, K. Ragliavachari, A. Rendell, J.C. Burant, S.S. Iyengar, J. Tomasi, M. Cossi, N. Rega, J.M. Millam, M. Klene, J.E. Knox, J.B. Cross, V. Bakken, C. Adamo, J. Jaramillo, R. Gomperts, R.E. Stratmann, O. Yazyev, A.J. Austin, R. Cammi, C. Pomelli, J.W. Ochterski, R.L. Martin, K. Morokuma, V.G. Zakrzewski, G.A. Voth, P. Salvador, J.J. Dannenberg, S. Dapprich, A.D. Daniels, J.B. ÖFarkasForesman, J.V. Ortiz, J. Cioslowski, D.J. Fox, Gaussion 09, Revision A.02. Gaussian, Inc, Wallingford CT, 2009.

[54] G. te Velde, F.M. Bickelhaupt, S.J.A. van Gisbergen, C. Fonseca Guerra, E.J. Baerends, J.G. Snijders, T. Ziegler, J. Comput. Chem. 22 (2001) 931-967.

[55] ADF 2010.01. in: V.U. SCM, Amsterdam (Ed.), edition 2005 ed., http://www. scm.com, Amsterdam, The Netherlands.

[56] D. Andrae, U. Haeussermann, M. Dolg, H. Stoll, H. Preuss, Theor. Chim. Acta 77 (1990) 123.

[57] P.H. Hariharan, J.A. Pople, Theor. Chim. Acta 28 (1973) 213-222.

[58] J.P. Perdew, K. Burke, M. Ernzerhof, Phys. Rev. Lett. 77 (1996) 3865-3868.

[59] C. Adamo, V. Barone, J. Chem. Phys. 110 (1999) 6158-6170.

[60] Y. Zhao, N.E. Schultz, D.G. Truhlar, J. Chem. Theory Comput. 2 (2006) 364-382.

[61] M. Cossi, N. Rega, G. Scalmani, V. Barone, J. Comput. Chem. 24 (2003) 669-681.

[62] E. van Lenthe, A. van der Avoird, P.E.S. Wormer, J. Chem. Phys. 107 (1997) 2488-2498.

[63] E. van Lenthe, A. van der Avoird, P.E.S. Wormer, J. Chem. Phys. 108 (1998) 4783-4796.

[64] A.D. Becke, Phys. Rev. A 38 (1988) 3098-3100.

[65] J.P. Perdew, Phys. Rev, B 33 (1986) 8822-8824.

[66] E. van Lenthe, A.E. Ehlers, E.J. Baerends, J. Chem. Phys. 110 (1999) 8943-8953.

[67] S. Clément, L. Guyard, M. Knorr, C. Däschlein, C. Strohmann, Acta Cryst. E65 (2009) 0528-u1861.

[68] H. Werner, M.A. Esteruelas, H. Otto, Organometallics 5 (1986) 2295.

[69] D. Huang, W.E. Streib, J.C. Bollinger, K.G. Caulton, R.F. Winter, T. Scheiring, J. Am. Chem. Soc. 121 (1999) 8087-8097.

[70] S. Jung, K. Ilg, C.D. Brandt, J. Wolf, H. Werner, Eur. J. Inorg. Chem. (2004) 469-480.
[71] N.W. Alcock, J. Cartwright, A.F. Hill, M. Marcellin, H.M. Rawles, J. Chem. Soc. Chem. Commun. (1995) 369-370.

[72] Y. Maruyama, K. Yamamura, T. Sagawa, H. Katayama, F. Ozawa, Organometallics 19 (2000) 1308-1318.

[73] M. Pichlmaier, R.F. Winter, M. Zabel, S. . Záliș, J. Am. Chem. Soc. 131 (2009) 4892-4903.

[74] J. Maurer, M. Linseis, B. Sarkar, B. Schwederski, M. Niemeyer, W. Kaim, S. Záliš C. Anson, M. Zabel, R.F. Winter, J. Am. Chem. Soc. 130 (2008) 259-268.

[75] K. Kowalski, M. Linseis, R.F. Winter, M. Zabel, S. Záliš, H. Kelm, H.-J. Krüger, B. Sarkar, W. Kaim, Organometallics 28 (2009) 4196-4209.

[76] D.E. Richardson, H. Taube, Coord. Chem. Rev. 60 (1984) 107-129.

[77] R.J. Crutchley, Adv. Inorg. Chem. 41 (1994) 273-325.

[78] Y.-C. Lin, W.-T. Chen, J. Tai, D. Su, S.-Y. Huang, I. Lin, J.-L. Lin, M.M. Lee, M.F. Chiou, Y.-H. Liu, K.-S. Kwan, Y.-J. Chen, Inorg. Chem. 48 (2009) $1857-1870$

[79] F. Barrière, N. Camire, W.E. Geiger, U.T. Mueller-Westerhoff, R. Sanders, J. Am Chem. Soc. 124 (2002) 7262-7263.

[80] D.M. D'Alessandro, F.R. Keene, Dalton Trans. (2004) 3950-3954.

[81] J. Maurer, R.F. Winter, B. Sarkar, J. Fiedler, S. Zális, Chem. Commun. (2004) 1900-1901

[82] F. Hartl, D.J. Stufkens, A. Vlček, Inorg. Chem. 31 (1992) 1687-1695.

[83] F. Hartl, A.K. Renfrew, F. Lafolet, T. Mahabiersing, M.J. Calhorda, S. ChardonNoblat, A. Deronzier, Inorg. Chem. 48 (2009) 8233-8244.

[84] S.J. Sherlock, D.C. Boyd, B. Moasser, W.L. Gladfelter, Inorg. Chem. 20 (1991) 3626-3632.

[85] (a) J. Maurer, B. Sarkar, B. Schwederski, W. Kaim, R.F. Winter, S. Zális, Organometallics 25 (2006) 3701-3712; (b) X.H. Wu, S. Jin, J.H. Liang, Y.Y. Li, G.-ao Yu, S.H. Liu, Organometallics 28 (2009) 2450-2459.

[86] W.Y. Man, J.-L. Xia, N.J. Brown, J.D. Farmer, D.S. Yufit, J.A.K. Howard, S.H. Liu, P.J. Low, Organometallics 30 (2011) 1852-1858

[87] M.A. Fox, R.L. Roberts, T.E. Baines, B. Le Guennic, J-F. Halet, F. Hartl, D.S. Yufit, D. Albesa-Jové, J.A.K. Howard, P.J. Low, J. Am. Chem. Soc. 130 (2008) 3566-3578.

[88] S. Záliš, R.F. Winter, W. Kaim, Coord. Chem. Rev. 254 (2010) 1383-1396.

[89] M. Renz, K. Theilacker, C. Lambert, M. Kaupp, J. Am. Chem. Soc. 131 (2009) $16292-16302$

[90] J. Maurer, B. Sarkar, W. Kaim, R.F. Winter, S. Záliš, Chem. Eur. J. 13 (2007) $10257-10272$.

[91] J. Maurer, B. Sarkar, S. Zalis, R.F. Winter, J. Solid State Electrochem. 9 (2005) $738-749$.

[92] M. Linseis, R.F. Winter, B. Sarkar, W. Kaim, S. Záliš, Organometallics 27 (2008) 3321-3324.

[93] M. Rudolph, S. Feldberg, DigiSim3, Version 3.03. Bioanalytical Systems, Inc, 1994.

[94] C.G. Atwood, W.E. Geiger, J. Am. Chem. Soc. 122 (2000) 5477-5485.

[95] S.V. Lindemann, S.V. Rosokha, J.K. Kochi, J. Am. Chem. Soc. 124 (2002) $843-855$.

[96] W. Weng, T. Bartik, M. Brady, B. Bartik, J.A. Ramsden, A.M. Arif, J.A. Gladysz, J. Am. Chem. Soc. 117 (1995) 11922-11931.

[97] G.F. Caramori, S.E. Galembeck, J. Phys. Chem. A 111 (2007) 1705-1712. 